\title{
Integrated Land Use Planning in Wadi El-Amal, Aswan Governorate, Egypt
}

\author{
Adel A. Elwan \\ Pedology Department, Water Resources and Desert Soils Division, Desert Research Center (DRC), Cairo, 11753, Egypt
}

Received: $27 / 5 / 2020$

\begin{abstract}
The study shows how to use cutting-edge geospatial technology to better assess desert resources and provides a systematic approach that can be used elsewhere under the same conditions. A total studied area of 19320 Faddan in Wadi El-Amal located in Aswan governorate, Egypt. This study area is a desert; however, haphazard planning, management practices, and inadequate investments result in land and water resource degradation. The pedomorphologial, physical, chemical, fertility characteristics of the selected soils were studied based on in-situ, remotely sensed and other data sources. Data on water geochemistry of water samples, collected from three dug wells were also utilized for this study. Five soil mapping units (SMUs) were prepared based on soil depth, rock fragments intensity and size, soil texture, and land topography. The SMUs are: (i) deep moderately fine textured soils with almost flat topography (4760 Faddan; 24.64\%), (ii) deep gravelly medium textured soils with gently undulating topography (4740 Faddan; 24.53\%), (iii) moderately deep gravelly coarse textured soils with gently undulating topography (3350 Faddan; $17.34 \%$ ), (iv) shallow cobbly coarse textured soils with undulating topography (2900 Faddan; $15.01 \%)$, and (v) very shallow stony coarse textured soils with undulating topography (3570 Faddan; 18.48\%). Different evaluation methods were utilized to characterize, evaluate, and plan the studied lands based on the collected data related to soil, water, environmental, political, and socioeconomic criteria. Three different evaluation methods namely qualitative desert land potentiality evaluation $\left(\mathrm{Q}_{\mathrm{L}} \mathrm{DLPE}\right)$, the American land capability classification (USDA LCC), and qualitative desert land aptness for crops $\left(\mathrm{Q}_{\mathrm{L}} \mathrm{DLAC}\right)$ were used to implement assess the potentiality and capability of the studied lands to produce various suitable crops. $\mathrm{Q}_{\mathrm{L}} \mathrm{DLPE}$ model has grouped the study area into four potentiality classes (high, moderate, slight, and low) while the USDA LCC system classified the study area into three capability classes (class-III, class-IV, and class-V). The characteristics of each soil unit were compared with the requirements of major crops of the study area and suitable crops for each unit were identified. Six land utilization types (field crops, vegetables, citrusfruits, oil crops, forages, aromatic plants) were suggested as value-added crops for cultivation following the precision farming technique. The results of the evaluation analyses were integrated to propose a sustainable plan through integrated desert land use planning (IDLUP) methodology. Accordingly, about of $66.51 \%$ of the total study area (12850 Faddan) was determined for agricultural development, while the rest area (33.49\%) was excluded from the agrarian expansion and may be used for the housing and constructions. Value-added crops were prioritized as follows: Field crops and vegetables (4760 Faddan) $>$ citrus-fruits and oil crops (4740 Faddan) $>$ medicinal, aromatic plants, and forages (3350 Faddan). The findings suggest strategies for coping with sustainable agricultural practices for the present study area and provide an integrated methodology for future assessments elsewhere, especially in the desert areas.
\end{abstract}

Keywords: Geospatial technologies; Land evaluation; Land use planning, Wadi El-Amal, Aswan

\section{INTRODUCTION}

Land and water are the basic natural resources on which the existence of humankind depends (Corato and Brady, 2019; Moonjun et al., 2020). In all aspects of land use planning, it is necessary to study the potentials, problems, utilization levels and suitability of land and water resources for various uses (Elwan and Sivasamy, 2013a; Ellili-Bargaoui et al., 2020). Agricultural development on newly reclaimed lands in Egypt has led to many national debates about food security and budget deficits, and the living conditions of the new settlers at the local level (Elwan, 2019). In this context, policymakers in Egypt are always seeking the best land allocation system for these new lands (Alary et al., 2018; Elwan, 2019). The Egyptian government has set a goal to end hunger, achieve food security, and improve nutrition through sustainable agriculture by the year 2030 (Alary et al., 2018). In order to realize this goal, profound changes in land use, especially in agriculture, to ensure sustainable food production and enhance incomes of small-scale food producers are necessary (Corato and Brady, 2019).

One of the most pressing scientific challenges in the coming decades is to increase agricultural

Corresponding author e-mail: dr.elwandrc@gmail.com production (Moonjun et al., 2020). Any land use recommendation without giving due consideration to soil resources and their constraints may not help to achieve the goal of sustainable agricultural production (Elwan and Sivasamy, 2013a). Many attempts were made by researchers to study the suitability of land and water for various uses. Initially, these kinds of suitability studies were qualitative in nature while quantitative aspects gained importance afterward (Elwan and Sivasamy, 2013b). In this context, integrated desert land use planning (IDLUP) methodology play an important role in increasing agricultural production of a desert region for applying the precision system through sustainable natural resources planning and management (Elwan and Sivasamy, 2013b; Elwan, 2019). Precision agriculture is an integrated crop management system that combines information technologies with rational agricultural industries and attempts to provide amounts and type of inputs based on actual needs of cultivation in small farms that are located inside a large farm (Tohidyan and Rezaei-Moghaddam, 2018; Ellili-Bargaoui et al., 2020).

Many pedo-morphological properties, such as color value, root abundance, and structure, are dynamic and influenced by land use type and management

Volume 5 (1): 31-48 
(Suther and Leigh, 2020). Studies have emphasized to use the pedo-morphological properties for land and soil quality evaluation (Juhos and Madarāsz, 2016; Suther and Leigh, 2020). However, most of the soil quality studies have only used the soil physical, chemical, and biological properties, ignoring the pedological context for the soil quality evaluation (Suther and Leigh, 2020). Suitability analysis of groundwater for irrigation purposes is also necessary for suggesting optimal planning measures because the groundwater is being increasingly used for agricultural production in semiarid regions (Elwan, 2013).

Geospatial technologies are now widely used in resources monitoring and estimation of hydrologic variables such as land evaluation and land use planning (Elwan, 2013). Many resource assessment approaches based on remote sensing can be easily extended to different models. Soil maps consist a collection of soil mapping units that are used to delineate areas with similar soil properties (Itichaa and Takeleb, 2019; Voltz et al., 2020). Many researchers have put a great effort into enhancing and increasing standardization of soil mapping units (Itichaa and Takeleb, 2019; ElliliBargaoui et al., 2020; Voltz et al., 2020).

Despite the merits of resource assessments as stated in many published research works, integrated assessments are seldom used (Elwan and Sivasamy, 2013b; Emmet-Booth et al., 2019; Ellili-Bargaoui et al., 2020). Detailed information on diverse properties is not available for El-Amal soils. Furthermore, information about environmental, socioeconomic, and political criteria is vital for planning sustainable management practices (Elwan, 2013; Emmet-Booth et al., 2019). Since most of the agricultural lands in developing countries are similar to these conditions, the present study is attempted as a case to develop a framework to assess the land and water resources potential, utilization level and land suitability for agriculture; and to evolve better management strategies (Elwan and Sivasamy, 2013a; Ellili-Bargaoui et al., 2020). Keeping these factors in mind, the current study aims at developing an extensive framework for assessing the land and water resources of an arid El-Amal watershed in order to achieve the goals of land use planning and agricultural sustainability. Specifically, the study was done to (i) characterize the soils based on their morphology, physical, chemical, and fertility properties (ii) identify the land potential limitations through applying land evaluation methods for determining reasonable agricultural development priorities, and (iii) guide the decision makers towards scientific management of existing land resources through suggesting an optimum land use plan.

\section{MATERIALS AND METHODS}

\section{Choice of the Study Area}

The study area, Wadi El-Amal area, comprises a part of Wadi Kurkur which is situated in the southern part of the Western Desert, southern Egypt. It lies 25 $\mathrm{km}$ to the southwest of Aswan, Egypt. As shown in Fig. (1), it sprawls between the latitudes of $23^{\circ} 50^{\prime}$ to $23^{\circ} 58^{\prime}$ North and longitudes of $32^{\circ} 32^{\prime}$ to $32^{\circ} 39^{\prime}$ East, and covers an area of about 19320 Faddan. The elevation ranges from 279 to $310 \mathrm{~m}$ above sea level (Fig. 1). The various rock types outcropping in the area produced different soil on several landscape positions. It starts from the tertiary rocks of southern mountainous and rocky terrains at summit, shoulder, and backslopes, then goes through the mixed sedimentary areas in the footslope, and finally ends with the Quaternary sediments at the toeslope in the north (El-Shazly et al., 1977; Said, 1962).

Wadi El-Amal study area is located at the Nubian plain within the middle reach of Wadi Kurkur. Wadi Kurkur is presently a dry riverbed and defunct tributary of the Nile Basin (Said, 1962). It traverses the main geomorphic provinces of the region: the Sinn ElKaddab Plateau, Nubian Plain, Red Sea Hills, and Nubian Swell (Gaber et al., 2018). With an average elevation of $350 \mathrm{~m}$, the Sinn El-Kaddab plateau is comprised of a $\sim 1 \mathrm{~km}$ thick sequence of Late Cretaceous-Early Eocene clastic and carbonate sediments (Issawi, 1978). This prominent carbonate tableland is extensive, stretching $\sim 300 \mathrm{~km}$ from northto-south and $\sim 100 \mathrm{~km}$ westward from Kurkur to the Darb El-Arbain escarpment, which borders the Kharga Oasis depression (Issawi, 1978). Such setting had facilitated ground water sapping during previous wet periods along the contacts of permeable fractured limestone and the impermeable shale (Gaber et al., 2018). The Nubia sandstone sequence in the study area consists of alternating beds of sandstone, shale, and clay (Issawi, 1978).

Climatological data from 1995 to 2019 were obtained from Aswan meteorological station by the Egyptian Meteorological Authority (2020). The study area is located in the desert climate belt (hyper-arid conditions), where it is characterized by hot dry summer and warm rainless winter. The average daily temperature of the site ranges from $13.5^{\circ} \mathrm{C}$ in January to $35^{\circ} \mathrm{C}$ in July, and the mean annual precipitation is 1.5 $\mathrm{mm}$. Such meteorological data were used for matching the climatic requirements of crops and identifying land utilization types through land aptness evaluation for crops. Socioeconomic measures and national policies are the dominant drivers of agricultural, urban, and industrial land development (Kuang et al., 2016). Based on field surveys and statistics data (Central agency for public mobilization and Statistics of Egypt, 2020), socioeconomic indicators (e.g., infrastructure, labor, agricultural technologies, human management, and markets) and political entities (e.g., decision making, agricultural policies, and land tenure) were collected for promoting land evaluation procedures.

\section{Remotely Sensed Data Acquisition}

ETM+ images of 2020, covering the study area in Aswan Governorate, Egypt, were used in the present study. The space images were collected and processed to be included in the GIS land resource database. Preprocessing commonly comprises a series of sequential operations, including radiometric correction or normalization, image registration, geometric correction, masking and image enhancement. The digital maps were corrected for different errors and edge-matched 
after the geo-referencing processes. Soil and land capability maps of Wadi El-Amal study area were developed in GIS format at different scales.

The chemical and physical characteristics of soil samples obtained from different soil units in the studied area were analyzed in the laboratory. The results of these analyses were recorded in database tables and then integrated into the attribute tables of digital GIS. Land capability classes were defined according to the rating of soil properties adapted from Gad (2015). According to the methodologies of applied land evaluation systems, each land quality was evaluated qualitatively based on its resiliency to the applicable constraints (Elwan, 2019). Land capability and potentiality maps were produced using GIS technology, depending on the potentiality/capability classes calculated in the established database.

\section{Sampling and Analyses}

The study comprises a series of tasks that were performed during pre-fieldwork, fieldwork, and postfieldwork stages. During the pre-fieldwork stage, preparation of base maps was undertaken for planning of soil and land survey activities. Base maps of the study area were created using ARC-GIS 10.1 software by overlaying a $30 \mathrm{~m}$ resolution LANDSAT ETM+ and Google Earth imagery. The derived attributes of slope, landform, and land use/land cover were used to delineate the study area boundary. The location and number of soil pedons that helped field survey activities were estimated and distributed on the base map at a specific resolution (Fig. 2).

During the fieldwork stage, all field investigations were done following a preliminary survey of the study site. Using the regular grid survey system, about 71 soil pedon were distributed across the toposequence of Wadi El-Amal area and physically located in the field using predetermined GPS coordinates (Fig. 2). The landscape variables such as elevation, landform, slope steepness, land use type, vegetation type, and parent materials were characterized according to FAO (2006) guideline and Schoeneberger et al. (2012). Soil pedons were excavated at each location to $1.5 \mathrm{~m}$ depth unless restricted by rock or water table. The Cr horizon was named in the field because of its "soft" rock nature (Soil Survey Staff, 2014a). At each locality, a cleaned profile was described and sampled following standard United States Department of Agriculture-Natural Resources Conservation Service (USDA-NRCS) methods (Schoeneberger et al., 2012; Soil Survey Division Staff, 2017). Field morphological descriptions included horizon nomenclature, horizon thickness and boundary, color, texture, structure, consistence, redoximorphic features, roots, and other pedo-morphological characteristics. Hereafter, soil samples were collected from each layer/horizon to evaluate pedomorphological, physical, chemical, and fertility characteristics of the studied soils. The entire study site was divided into five major soil mapping units (SMUs) using soil and landscape data. The SMUs were delineated based on criterions such as soil depth, soil texture, rock fragments intensity/size, and land topography to develop soil units that have similar characteristics.

Post-fieldwork activities were focused on soil analyses in the laboratory, geospatial mapping and evaluation recommendations. Horizontally oriented soil samples were taken from soil pedons for laboratory analyses. Collected soil samples were air dried and separated through $2 \mathrm{~mm}$ sieve size based on the standard procedures given by Van Reeuwijk (1993). The coarse rock fragments content $(>2 \mathrm{~mm}$ in diameter) was considered as gravel $(2-76 \mathrm{~mm})$, cobbles $(>76-250$ $\mathrm{mm})$, stones $(>250-600 \mathrm{~mm})$, and boulders $(>600 \mathrm{~mm})$ (Soil Survey Division Staff, 2017). This coarse fraction was determined for each soil sample using the equation: rock fragments content $\%=$ (weight of coarse materials/weight of coarse and fine materials $) \times 100$ (Soil Survey Staff, 2014b).

After sieving, the finer samples $(<2 \mathrm{~mm})$ were packed in the polythene bags for determination of physical, chemical, and nutrient characteristics. Particlesize analyses were determined using dry sieving and the pipette method (Soil Survey Staff, 2014b). Available water content (A.W), EC, soluble cations and soluble anions, sodium adsorption ratio (SAR), $\mathrm{pH}, \mathrm{CEC}$, $\mathrm{CaCO} 3$, gypsum, and organic matter (O.M) were estimated as per the standard procedures (Jackson, 1973; Page et al., 1982; Van Reeuwijk, 1993; Soil Survey Staff, 2014b). The available concentration of nitrogen was estimated using Kjeldahl distillation method (FAO, 1970). Standard methods given by Soltanpour and Schwab (1977) were used for estimating available concentrations of phosphorus and potassium. Available concentrations of micronutrients $(\mathrm{Zn}, \mathrm{Cu}, \mathrm{Mn}$, and $\mathrm{Fe}$ ) were determined according to Lindsay and Norvell (1978). Groundwater samples were geochemically analyzed as per the standard procedures and methods (Mani et al., 2007). Then, quality of groundwater was assessed according to Ayres and Westcott (1976).

\section{Land Evaluation and Land Use Planning Methods}

Method used in the current research is the integration among field observation, soil laboratory analyses, and land evaluation results. Three systems of land evaluation namely qualitative desert land potentiality evaluation $\left(\mathrm{Q}_{\mathrm{L}} \mathrm{DLPE}\right)$, the American land capability classification (USDA LCC), and qualitative desert land aptness for crops $\left(\mathrm{Q}_{\mathrm{L}} \mathrm{DLAC}\right)$ were used to determine the potentiality and capability of the studied lands to produce various crops. They were integrated and linked to the integrated desert land use planning (IDLUP) procedure to plan of the study area. The basic principles of $\mathrm{Q}_{\mathrm{L}} \mathrm{DLPE}, \mathrm{Q}_{\mathrm{L}} \mathrm{DLAC}$ and IDLUP methods are not described in details here, but the details can be found in Elwan $(2013 ; 2019)$. They briefly discuss henceforth. 


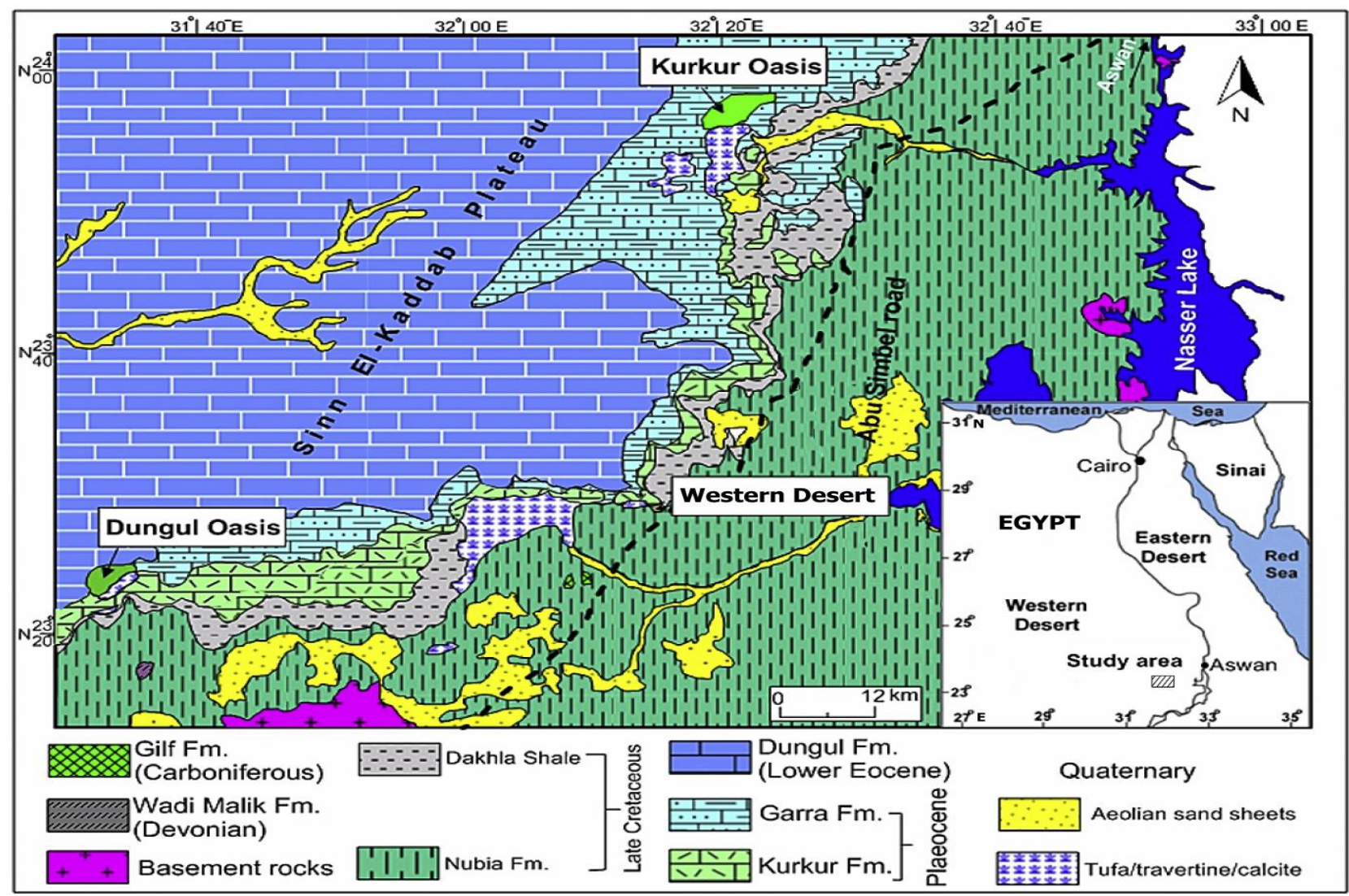

Fig. (1): Location of study area showing the geology formation.

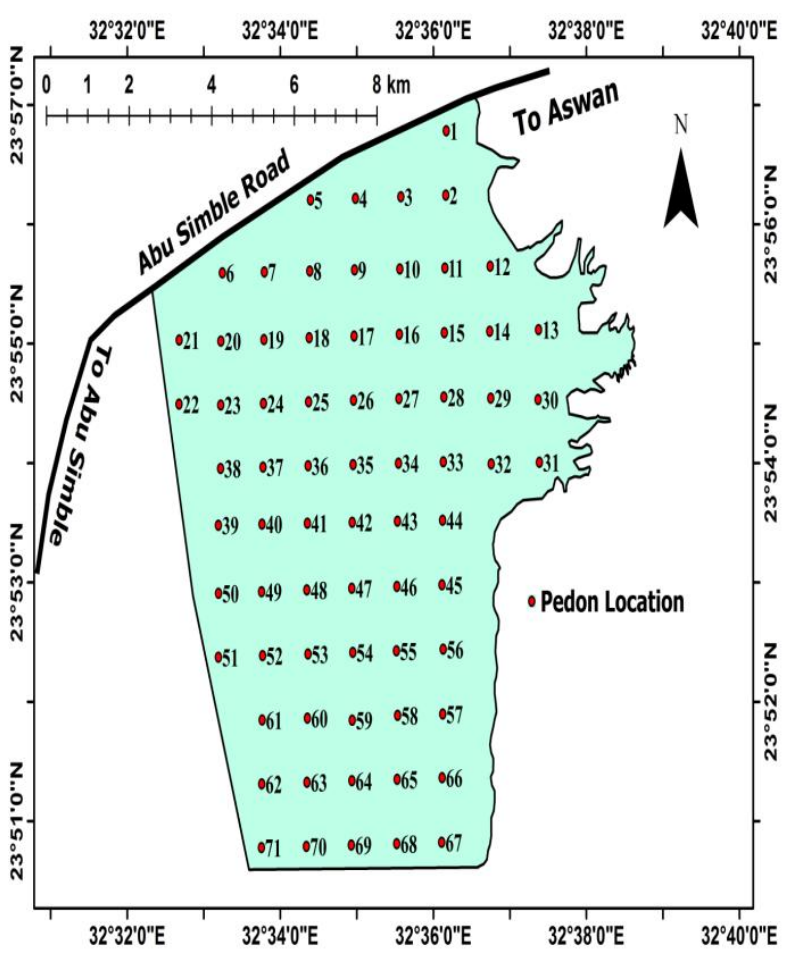

Fig. (2): Regular grid survey system of pedon locations across the study area

\section{$Q_{L}$ DLPE model}

$\mathrm{Q}_{\mathrm{L}} \mathrm{DLPE}$ model is originally devised for the agricultural rating of desert land, in particular, for hyper-arid, arid, and semi-arid zones (Elwan, 2013; 2019). Ratings are generated from a wide range of pedon and landscape characteristics as well as the socioeconomic and political factors. It involves the calculation of a potentiality index on the basis of twenty-two factors, each of which is given a numeric weight and rating value. The significance of each of the criteria regarding sustainability is not equal. In other words, different aspects have different impacts/weights on sustainability. Accordingly, the weight of each factor considered in this model is determined separately. Criteria weight is assumed between zero and one (decimal numbers) based on their contribution in the crop productivity. The numerical rating values of criteria are set between 0 and 100 based on the degree and kind of the limitations (Elwan, 2013; 2019). The criteria involved referring to the environment, soil, socioeconomic status, and political entity. Environmental criteria comprise water availability, topography, and natural hazards. Soil criteria include effective soil depth, coarse fragments, texture, soil water retention, drainage, $\mathrm{pH}, \mathrm{CaCO}_{3}$, salinity, gypsum, fertility status, and matrix color. Furthermore, socioeconomic status discusses the availability of infrastructure, labors (manpower), technologies, human management, and markets. Nevertheless, the political entity is related to the right of making decisions, agricultural policies, and land tenure. Then, the totality of all the criteria percentages is calculated by Eq. (1) for $\mathrm{Q}_{\mathrm{L}} \mathrm{DLPE}$ as follows:

$$
\begin{aligned}
\boldsymbol{L P I}= & \left\{\left(R_{1} \times W_{1}\right)+\left(R_{2} \times W_{2}\right)+\left(R_{3} \times W_{3}\right)+\left(R_{4} \times W_{4}\right)\right. \\
& \left.+\left(R_{5} \times W_{5}\right)+\left(R_{6} \times W_{6}\right)+\left(R_{n} \times W_{n}\right) .\right\} \ldots \ldots
\end{aligned}
$$

Where $L P I$ is the land potentiality index percentage, $R$ is the rating score, $W$ is the weighting score, and the subscript numbers $\left(1,2,3,4,5,6\right.$, and $\left.{ }_{n} \ldots\right)$ stand for twenty- 
two land criteria related to environment, soil pedon, socioeconomic measures, and political entity. The resultant index obtained is positioned to a potentiality category of the land. The potential categories are as: (i) high potential land (81-100\%); (ii) moderate potential land (66-80\%); (iii) slight potential land (46-65\%); (vi) low potential land $(26-45 \%)$; and (v) non-potential land $(<25 \%)$ (Elwan, 2013; 2019).

\section{USDA LCC model}

Land capability classification used in this study is according to USDA classification (Klingebiel and Montgomery, 1973; Helms, 1992; Gad, 2015). Land are classified into eight classes depend on the intensity and type of limitation factor. The classification system consists of capability class, capability subclass, and capability unit. Land was grouped in a class based on landscape, slope, soil depth, texture, and soil reaction. Subclasses were recognized for specific limitations such as erosion, excess wetness, rooting zone constriction, and climatic limitation. Capability units are grouped based on similar criteria related to landscape, soil, and water characters for plant growth. Class-I to class-IV are suited land for cultivation, while class- $\mathrm{V}$ to classVIII are generally not suited land for cultivation. The main properties of class-I (very highly capable land) have very few limitations. Class-II (highly capable land) has some limitations that reduce plant growth and needs moderate conservation measures. Class-III (moderately capable land) has medium risk and need special conservation practice. Class-IV (low capable land) has high grade of liability/high risk and severe limitations that reduce the choice of plant can be cultivated and need very careful conservation practice. Class-V (very low capable land) has very high grade of liability/very high risk (Gad, 2015). Class-VI to Class-VIII has extremely severe limitation so generally not suited to cultivate plant (Klingebiel and Montgomery, 1973).

\section{Land aptness evaluation for crops approach}

Qualitative desert land aptness for crops $\left(\mathrm{Q}_{\mathrm{L}} \mathrm{DLAC}\right)$ has been used to assess the desert land aptness for predicting a variety of added-valued crops based on six criteria including climate, environment, soil, agricultural policies, agricultural research technology, and market responses as per the guidelines given by Elwan $\left(2013\right.$; 2019). Q ${ }_{\mathrm{L}}$ DLAC model is a powerful tool to predict one or more outputs according to one or more input in a learning procedure. Adaptation to the guidelines was made as necessary based on climate, environment, field and laboratory findings. The process of this evaluation is the matching of crop growth requirements against land characteristics (criteria). The climate sub-criteria are air temperature, evapotranspiration, relative humidity, wind velocity, and precipitation. The environmental sub-criteria are irrigation water availability, topography of the landscape, and environmental hazards. While the soil sub-criteria are effective soil depth, soil texture, coarse fragments, soil salinity $(\mathrm{EC})$, soil reaction $(\mathrm{pH})$, lime content $\left(\mathrm{CaCO}_{3}\right)$, gypsum content, soil moisture, drainage, and fertility status. Agricultural policies are crop insurance, land tenure, and decision making, to select the varieties of crops which achieving food security according government plan. In this approach, four aptness classes (high, moderate, slight, and nonaptness) are differentiated based on the matching process and the degree of limitations. During aptness analyses, the selection of final aptness class is based on the weights of the criteria/sub-criteria. Climate, irrigation water availability, and solum depth factors have high weights (Elwan, 2013, 2019).

\section{IDLUP methodology}

IDLUP is a logical decision-making process in which desert resources are assessed using various evaluation methods in the context of objectives, and thus potential options that can be implemented by the land user are identified (Elwan, 2013, 2019). It is an extremely complex subject, combining socioeconomic of land use, institutional aspects, and technological interventions with an assessment of potential future requirements (Elwan, 2013, 2019). Ultimately, IDLUP is a set of systematic technical procedures to evaluate the offered options given by the used evaluation methods. The main criteria of IDLUP model are integrated into GIS to obtain appropriate scores indicating the sustainability status of the value-added crop production and their priorities. Every landuse planning project is different. Objectives and local circumstances are extremely varied, so each plan will require a different treatment. However, a sequence of five steps has been found useful as a guide for landuse planning of desert areas (Elwan, 2013). The main steps of IDLUP procedure are: (i) identifying and analyzing the current land use situation in the field through characterizing soil, water, socioeconomic measures; (ii) determining what alternative solutions exist through applying the specialized desert land evaluation methods; (iii) choosing the best option based on the above evaluation discussions, and deciding which crops to grow and which technologies to apply; (iv) allocating land to different kinds of uses in respect to institutional arrangements; and (v) specifying management standards and inputs (Elwan, 2019).

\section{RESULTS AND DISCUSSION}

\section{Soil Mapping Units}

The site was divided into five soil mapping units (SMUs), as shown in Fig. (3). Topography, soil depth, and soil texture were used to classify soil mapping units. The identified USDA soil textural groups were based on Schoeneberger et al. (2012). The SMUs are: (i) deep moderately fine textured soils with almost flat topography, (ii) deep gravelly medium textured soils with gently undulating topography, (iii) moderately deep gravelly coarse textured soils with gently undulating topography, (iv) shallow cobbly coarse textured soils with undulating topography, (v) very shallow stony coarse textured soils with undulating topography. The first soil mapping unit (SMU1) covered an area of 4760 Faddan (24.64\%) and developed on toeslope position. It occurred on nearly level slopes dominated by deep $(>100 \mathrm{~cm})$ moderately fine textured soils (clay loam, sandy clay loam, silty 
clay loam). Natural drainage within pedon layers varied from moderately well drained to somewhat poorly drained. This map unit consists deep $(<150 \mathrm{~cm})$ to very deep $(>150 \mathrm{~cm})$ soils containing less than $15 \%$ of gravel throughout soil pedon layers. These two soils often occur so closely associated that it is impractical to separate them during mapping. Hence, they are mapped as a complex of two similar soils.

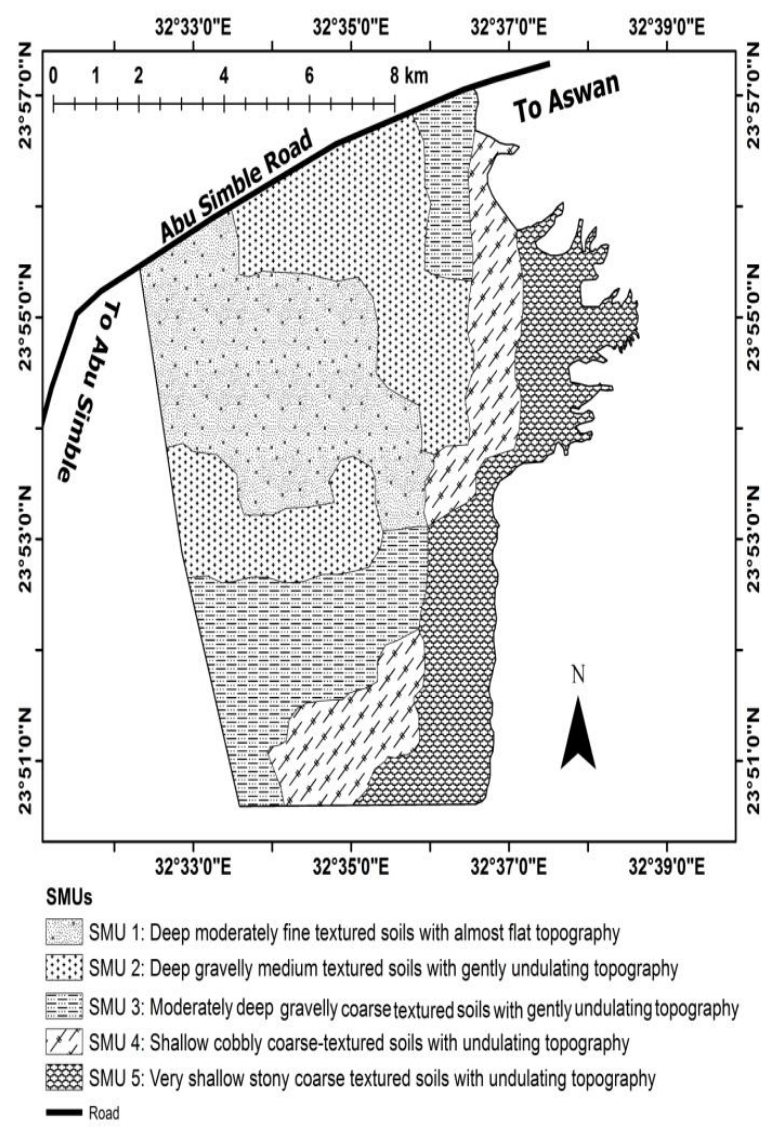

Fig. (3): Delineated soil mapping units of the study area using Arc-GIS technique

The SMU2 occupy an area of 4740 Faddan $(24.53 \%)$. Soils of this unit consist of deep, moderately well drained soils formed in very fine sandy loam alluvial material underlain by water-sorted sand and gravel. These soils were developed on gentle slopes (1$2 \%$ at footslope positions of plain landforms comprising soils enriched with loam and silt loam. Because of seasonal deposition of finer soil materials, they showed medium textured soils deeper than $100 \mathrm{~cm}$.
The SMU3 covered an area of 3350 Faddan (17.34\%) and formed at backslope geomorphic position (Fig. 3). It was prevalent along the plain landforms having uniform slopes of 5-7\% dominated by moderately deep $(100->50 \mathrm{~cm})$ cobbly coarse textured soils. These soils showed high concentration of cobbles $(>15$ to $<35 \%$ ) with undulating topography. SMU4 occupied an area of 2900 Faddan (15.01\%) and formed on shoulder position. The soils were formed at foot to mid-slope position in version land comprising a wide range of slope gradient $(5-15 \%)$. Soils of the SMU5 covered an area of 3570 Faddan on shoulder position geomorphic unit. These soils were very shallow $(<25$ $\mathrm{cm})$ and dominated by stones $(>35)$ and coarse textured soils. Both SMU4 and SMU5 were widespread at shoulder position and dominated by sand and loamy sand soils shallower than $50 \mathrm{~cm}$. Soils of these land units showed wide gravelly and stony surfaces with sandy loam texture.

\section{Groundwater Quality}

The main water resource for agricultural purposes in the study area is the groundwater which is available in limited amounts. Groundwater is available from different water-bearing formations of different lithology including sandstone, limestone, and fractured basement. This water source occurs under different hydrogeological conditions which may be free water, semi-confined, and confined or flowing springs conditions. Groundwater potentialities of Wadi El-Amal are promising for agriculture as it is available from different aquifers related to Wadi fill, Duwi (limestone and phosphate beds intercalations), and Nubia sandstone formations. They have a good thickness and away from seawater intrusion. Furthermore, Nubia formation existed at shallow depths.

Quality of irrigation water plays a major role in deciding crop yields. Water samples were collected from three different wells located in different soil mapping units $\left(1^{\text {st }}\right.$ sample from SMU1, $2^{\text {nd }}$ sample from SMU2, and $3^{\text {rd }}$ sample from SMU3). The results of geochemical analysis of groundwater samples (Table 1) showed that the average concentration of $\mathrm{pH}$ varied from 7.35 to 8.01 indicates that groundwater of the study area is very hard in nature, and hardness is mainly due to the bicarbonate salts of calcium and magnesium. Regarding the groundwater quality of third soil mapping unit (SMU3), the concentration of boron was in moderate and chloride was in severe limits, where their values were $0.94 \mathrm{mg} / \mathrm{l}$ and $19.2 \mathrm{meq} / \mathrm{l}$, respectively.

Table (1): Chemical composition of groundwater samples collected from three wells across soil mapping units

\begin{tabular}{|c|c|c|c|c|c|c|c|c|c|c|c|c|}
\hline \multirow{2}{*}{$\begin{array}{l}\text { Well } \\
\text { No. }\end{array}$} & \multirow{2}{*}{$\mathbf{S M U}^{\mathbf{a}}$} & \multirow{2}{*}{ pH } & \multirow{2}{*}{$\begin{array}{c}E C_{w}{ }^{b} \\
(d S / m)\end{array}$} & \multicolumn{3}{|c|}{$\begin{array}{c}\text { Soluble cations } \\
(\mathrm{meq} / \mathrm{l})\end{array}$} & \multirow{2}{*}{$\mathbf{S A R}^{\mathrm{c}}$} & \multicolumn{4}{|c|}{ Soluble anions (meq/l) } & \multirow{2}{*}{$\begin{array}{c}\text { B } \\
(\mathrm{mg} / \mathrm{l})\end{array}$} \\
\hline & & & & $\mathrm{Ca}^{+2}$ & $\mathrm{Mg}^{+2}$ & $\mathrm{Na}^{+}$ & & $\mathrm{Cl}^{-}$ & $\mathrm{SO}_{4}^{-2}$ & $\mathrm{HCO}_{3}^{-}$ & $\mathrm{CO}_{3}^{-2}$ & \\
\hline 1 & SMU1 & 7.35 & 0.70 & 1.05 & 0.86 & 5.15 & 3.49 & 4.77 & 0.88 & 1.35 & 0.07 & 0.29 \\
\hline 2 & SMU2 & 7.78 & 1.47 & 4.42 & 2.01 & 8.25 & 5.75 & 10.20 & 2.01 & 2.09 & 0.20 & 0.38 \\
\hline 3 & SMU3 & 8.01 & 2.81 & 6.31 & 3.88 & 16.98 & 7.52 & 17.95 & 1.65 & 3.39 & 0.15 & 0.94 \\
\hline
\end{tabular}


$\mathrm{EC}_{\mathrm{w}}$ and SAR values were found within severe limits. Among the cations, sodium is a dominant constituent, which possesses more than $50 \%$ of ions in the overall concentration of all cationic elements. While analyzing the major constituents of the anions, it is found that the chloride ion has a higher concentration than bicarbonate followed by sulphate and carbonate in the groundwater samples. Accordingly, the quality of groundwater was placed under permissible conditions. On the contrast, results of groundwater samples of first soil mapping unit (SMU1) well showed that its quality was rated as good water for irrigation without salinity or alkalinity hazards for crops.

\section{Soil Morphology}

Soil morphology is affected by climate, land use, farming systems, and seasonal variations (Suther and Leigh, 2020). Generally, soils are studied for their morphology at an appropriate moisture level between field capacity and permanent wilting point for better visualization and understanding of the pedogenic processes. Major morphological properties of sites and pedons of Wadi El-Amal are presented in Table (2), and visualized in Fig. (4). The morphology of the soil mapping units (SMUs) on toeslope differed from that of the soils on upland shoulder in their effective depth, soil color, concentrations, redoximorphic features, and the absence or presence of diagnostic horizons. The soils of first mapping unit showed 3-4 layers described as follows (Table 2 and Fig. 4): a $35 \mathrm{~cm}$ reddish yellow (7.5YR 6/6) silt loam Ap anthropic horizon on top of a $20 \mathrm{~cm}$ brownish yellow (10YR 6/8) sandy clay loam calcic horizon. By contrast, the solum was absent in the studied lands on higher slope positions whereas the subsolum layers; e.g., regolithic layer (C), saprolithic $(\mathrm{Cr})$, and paralithic layers (R), defined by MoraguesQuiroga et al., 2017, were noticed at different depths (Fig. 4). Furthermore, saprolithic (Cr), and paralithic layers (R) were only noticed in the shoulder pedons (SMU4 \&SMU5) as in Fig. (6). They were represented by a very pale brown (10YR 8/2) sand $\mathrm{C}$ layer, and light gray (10YR 7/2) sandy Cr layer.

The soil color of all pedons was widely varied from 7.5YR to $10 \mathrm{YR}$ in hue, 5 to 8 in value, and 2 to 8 in chroma (Table 2). The soil color ranged from reddish yellow $(7.5$ YR $6 / 6)$ at the surface horizons to light gray (10YR 7/2) at the subsurface layers (Fig. 4). In the third soil mapping unit (SMU3) on backslope position, an abrupt change from the top to the bottom in their dominant color, from brownish yellow $(7.54 / 2)$ to very pale brown (10YR 8/2), was observed.

There was a considerable variation in grade, size, and the shape of soil structure characteristics within each pedon and among soil mapping units. The pedons at toeslope position exhibited a moderate fine subangular blocky and weak medium granular structure in the Ap soil horizon and from moderate medium angular blocky to the weak medium subangular blocky structure in the calcic soil horizons, and consistence from slightly hard to extremely hard when dry. The studied pedons occurred on upland shoulder exhibited structureless units (e.g., single grain or massive) throughout the pedon layers and consistence from nonsticky to moderately sticky and nonplastic to moderately plastic when wet (Table 2 and Fig. 4).

Common redoximorphic features, as an indication of the presence of periodic saturation of upper parts of pedon, were observed as ferriargillans or manganese films in the soils studied of SMU1. Iron was oxidized mostly on the surfaces layers that were dominantly reddish brown. Therefore, the calcic horizon ( $\mathrm{Ckkm})$ was formed which is an altered horizon and strongly developed due to accumulation of secondary $\mathrm{CaCO}_{3}$. Masses of $\mathrm{Fe}$ or $\mathrm{Mn}$ and redox features were common in the studied soils in Wadi El-Amal study area. Petrocalcic and cemented horizons restrict root penetration. Furthermore, poorly aerated, and poorly drained soils can limit root system development.

\section{Soil Physical Properties}

Gravel, fine-earth fractions, and soil available water (A.W.) are presented in Table (3). The gravel content increased significantly in the shoulder and backslope positions and ranged from $19.44 \%$ to $34.25 \%$ for the respective $\mathrm{C}$ and $\mathrm{Cr}$ layers (Table 3 and Fig. 4). The abrupt increase and the change in the size of rock fragments between $\mathrm{C}$ and $\mathrm{Cr}$ layers evidenced a lithologic discontinuity. The lower slope positions (toeslope and footslope) had a gravel content ranging from $2.07 \%$ to $21.04 \%$ in the Ckkm layers in the SMU1 and SMU2. In contrast, the studied soils at toeslope and footslope position (e.g., SMU1 and SMU2) had rock fragments in gravel size compared with those soils on at backslope and shoulder (e.g., SMU4 and SMU5) which had rock fragments more than $15 \%$ in cobbles and stones size.

Soils across all landscapes showed differences in particle size distribution (Table 3). With decreasing slope and elevation above sea level, the clay fraction in all upper soil horizons in the studied soils increases significantly. Whereas clay concentration in the surface horizons of downslope soils were $37.15 \%$ in clay loam texture to $20.5 \%$ forming sandy clay loam texture in the surface layer of pedon 23 (Table 3). By contrast, clay fraction within pedons backslope and shoulder was similarly low at $9.45 \%$ and $1.25 \%$, respectively, compared with those of the toeslope and footslope soils. Meanwhile, sand-sized particles dominated the fineearth fractions across upper slope position, with a general decrease in sand content with decreasing elevation.

Soil available water values increased with decreasing elevation across the toposequence and showed values between 23.55-30.14\% in SMU1, 15.95$19.25 \%$ in SMU2, 5.36-9.15\% in SMU3, 5.15-7.36\% in SMU4, and 4.25-6.45\% in SMU5 (Table 4). The highest values of A.W. were in the lowland soils, which may be attributed to the high concentrations of clay and organic carbon. 
Table (2): Soil morphology and pedogenic features of representative pedons over soil mapping units across study area

\begin{tabular}{|c|c|c|c|c|c|c|c|c|c|c|c|c|}
\hline SMU & $\begin{array}{c}\text { Pedon } \\
\text { No. }\end{array}$ & $\begin{array}{c}\text { Horizon } \\
\text { /layer }\end{array}$ & $\begin{array}{l}\text { Depth } \\
\text { interval } \\
(\mathrm{cm})\end{array}$ & $\begin{array}{l}\text { Matrix } \\
\text { color } \\
\text { (Moist) }^{\mathrm{a}}\end{array}$ & $\begin{array}{c}\text { Structure } \\
\text { (Grade, size, } \\
\text { type) }\end{array}$ & 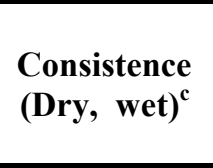 & $\begin{array}{l}\text { Redoximorphi } \\
\text { c features } \\
\text { (Kind) }{ }^{\mathrm{d}}\end{array}$ & $\begin{array}{c}\text { Concentrations } \\
\text { (Quantity, size, } \\
\text { kind, location, } \\
\text { hardness) }^{\text {e }}\end{array}$ & $\begin{array}{c}\text { Surface } \\
\text { cover } \\
\text { (kind, Size) }^{k}\end{array}$ & $\begin{array}{l}\text { Root } \\
\text { restriction } \\
(\text { Kind })^{\mathrm{h}}\end{array}$ & $\begin{array}{l}\text { Natural } \\
\text { drainage }\end{array}$ & $\begin{array}{c}\text { Slope } \\
\text { position \& } \\
\text { gradient }\end{array}$ \\
\hline \multirow{7}{*}{ I } & \multirow{4}{*}{21} & $\bar{C}$ & $0-35$ & $7.5 \mathrm{YR}$ & $0, \mathrm{MA}$ & SH, SS-SP & RMX \& F3M & f,CAM,TOH & \multirow{4}{*}{$\mathrm{SG}, \mathrm{GR}$} & \multirow{4}{*}{ Petrocalcic } & \multirow{4}{*}{$\begin{array}{l}\text { Moderat } \\
\text { ely well } \\
\text { drained }\end{array}$} & \multirow{4}{*}{$\begin{array}{l}\text { Toeslope \& } \\
\text { nearly level }\end{array}$} \\
\hline & & CK & $35-105$ & $7.5 \mathrm{YR}$ & $1, \mathrm{~F}, \mathrm{ABK}$ & HA,SS-SP & FEF \& F3M & $\mathrm{c}, 2, \mathrm{CAN}, \mathrm{MAT}$ & & & & \\
\hline & & Ckm & $105-130$ & $7.5 \mathrm{YR}$ & $2, \mathrm{M}, \mathrm{SBK}$ & VH, MS-SP & FEF \& F3M & $\mathrm{f}, 1, \mathrm{CAN}, \mathrm{TOH}$ & & & & \\
\hline & & Ckkm & $130-155$ & $7.5 \mathrm{YR}$ & $2, \mathrm{~F}, \mathrm{SBK}$ & MH, MS-MP & CLD \& RMX & $\mathrm{m}, 1, \mathrm{CAN}, \mathrm{MAT}$ & & & & \\
\hline & \multirow{3}{*}{35} & Ap & $0-25$ & 10YR & $0, \mathrm{MA}$ & "HA,MS-MP & FEF \& F3M & "m,2,CAC,MAT & \multirow{3}{*}{ SG, GR } & \multirow{3}{*}{$\begin{array}{l}\text { Cemented } \\
\text { horizon } \\
(\mathrm{CH})\end{array}$} & \multirow{3}{*}{$\begin{array}{l}\text { Somewh } \\
\text { at poorly } \\
\text { drained }\end{array}$} & \multirow{3}{*}{$\begin{array}{l}\text { Toeslope \& } \\
\text { nearly level }\end{array}$} \\
\hline & & $\mathbf{C k}$ & $25-90$ & $10 \mathrm{YR}$ & $2, \mathrm{M}, \mathrm{ABK}$ & EH,MS-MP & FED \& F3M & $\mathrm{c}, 2, \mathrm{CAN}, \mathrm{MAT}$ & & & & \\
\hline & & Ckkm & $90-140$ & $10 \mathrm{YR}$ & $1, \mathrm{CO}, \mathrm{SBK}$ & VH, SS-SP & RMX \& F2M & $\mathrm{c}, 1, \mathrm{CAN}, \mathrm{MAT}$ & & & & \\
\hline \multirow{4}{*}{ II } & \multirow{4}{*}{49} & $\mathbf{C}$ & $0-30$ & $10 \mathrm{YR}$ & 0, MA & SH,SS-SP & RMX \& F2M & f,1,CAN,MAT & \multirow{4}{*}{$\begin{array}{l}\text { SG, GR \& } \\
\text { CB }\end{array}$} & \multirow{4}{*}{$\begin{array}{c}\text { Strongly } \\
\text { contrasting } \\
\text { textural } \\
\text { stratificatio } \\
\text { n (SR) }\end{array}$} & \multirow{4}{*}{$\begin{array}{l}\text { Moderat } \\
\text { ely well } \\
\text { drained }\end{array}$} & \multirow{4}{*}{$\begin{array}{l}\text { Footslope } \\
\text { \& very } \\
\text { gently } \\
\text { sloping }\end{array}$} \\
\hline & & $\mathbf{C k}$ & $30-70$ & $10 \mathrm{YR}$ & 0, MA & MH,MS-MP & FEF \& F3M & $\mathrm{c}, 2, \mathrm{CAC}, \mathrm{TOH}$ & & & & \\
\hline & & Ckkm & $70-110$ & $10 \mathrm{YR}$ & $2, \mathrm{~F}, \mathrm{SBK}$ & MH,SO-PO & FED \& FMN & $\mathrm{m}, 1, \mathrm{CAN}, \mathrm{ARF}$ & & & & \\
\hline & & Ckm & $110-145$ & $\begin{array}{l}10 \mathrm{YR} \\
7 / 8\end{array}$ & 0, SGR & MH,SO-PO & FMC \& FMN & m,2,CAN,ARF & & & & \\
\hline \multirow{4}{*}{ III } & \multirow{4}{*}{52} & $\mathbf{C}$ & $0-20$ & $10 \mathrm{YR}$ & $0, \mathrm{MA}$ & $\mathrm{SH}, \mathrm{SS}-\mathrm{SP}$ & FMC \& FMN & f,1,CAM,SPO & \multirow{4}{*}{$\begin{array}{c}\text { SED, GR \& } \\
\text { CB }\end{array}$} & \multirow{4}{*}{$\begin{array}{c}\text { Petrocalcic } \\
(\mathrm{PE})\end{array}$} & \multirow{4}{*}{$\begin{array}{l}\text { Somewh } \\
\text { at poorly } \\
\text { drained }\end{array}$} & \multirow{4}{*}{$\begin{array}{l}\text { Backslope } \\
\& \text { gently } \\
\text { sloping }\end{array}$} \\
\hline & & $\mathbf{C k}$ & $20-40$ & $10 \mathrm{YR}$ & 0, MA & EH,SS-SP & FMN \& F3M & $\mathrm{c}, 1, \mathrm{CAC}, \mathrm{MAT}$ & & & & \\
\hline & & Ckm & $40-65$ & $10 \mathrm{YR}$ & $2, \mathrm{~F}, \mathrm{SBK}$ & VH, SS-SP & FMC \& FMN & $\mathrm{m}, 2, \mathrm{CAN}, \mathrm{ARF}$ & & & & \\
\hline & & $2 \mathrm{C}$ & $65-95$ & $10 \mathrm{YR}$ & $2, \mathrm{~F}, \mathrm{SBK}$ & VH,MS-MP & FMC \& FMN & $\mathrm{m}, 1, \mathrm{CAN}, \mathrm{ARF}$ & & & & \\
\hline \multirow[b]{2}{*}{ IV } & \multirow[b]{2}{*}{63} & $\mathbf{C}$ & $0-30$ & 10YR & $2, \mathrm{M}, \mathrm{PL}$ & SH,SO-PO & None & f,1,CAM,SPO & \multirow[b]{2}{*}{ RK, ST } & \multirow{2}{*}{$\begin{array}{c}\text { Densic } \\
\text { bedrock }\end{array}$} & \multirow{2}{*}{$\begin{array}{l}\text { Poorly } \\
\text { drained }\end{array}$} & \multirow{2}{*}{$\begin{array}{l}\text { Shoulder \& } \\
\text { gently } \\
\text { sloping }\end{array}$} \\
\hline & & $2 \mathrm{Cr}$ & $30-45$ & $\begin{array}{l}10 \mathrm{YR} \\
7 / 6\end{array}$ & 0, MA & $\mathrm{SH}, \mathrm{SO}-\mathrm{PO}$ & None & $\mathrm{m}, 2, \mathrm{CAN}, \mathrm{ARF}$ & & & & \\
\hline \multirow[b]{2}{*}{$\mathbf{V}$} & \multirow[b]{2}{*}{66} & $\mathrm{Cr}$ & $0-15$ & $10 \mathrm{YR}$ & $3, \mathrm{~F}, \mathrm{PL}$ & VH,SO-PO & None & $\mathrm{f}, 1, \mathrm{CAN}, \mathrm{ARF}$ & \multirow[b]{2}{*}{ BR, BY } & \multirow{2}{*}{$\begin{array}{l}\text { Paralithic } \\
\text { bedrock } \\
\text { (BPL) }\end{array}$} & Very & \\
\hline & & $\mathbf{R}$ & $15-20$ & $\begin{array}{l}10 \mathrm{YR} \\
7 / 2\end{array}$ & $0, \mathrm{SGR}$ & $\mathrm{SH}, \mathrm{SO}-\mathrm{PO}$ & None & $\mathrm{f}, 2, \mathrm{CAN}, \mathrm{MAT}$ & & & $\begin{array}{l}\text { poorly } \\
\text { drained }\end{array}$ & $\begin{array}{l}\text { Shoulder \& } \\
\text { sloping }\end{array}$ \\
\hline
\end{tabular}

All symbols are used based on Schoeneberger et al. (2012).

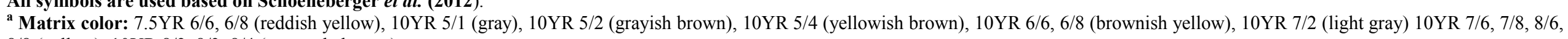
$8 / 8$ (yellow), 10YR 8/2,8/3,8/4 (very pale brown).

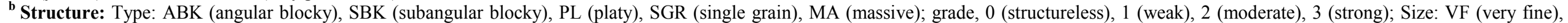
$\mathrm{F}$ (fine), M (medium) CO (coarse), VC (very coarse), EC (extremely coarse).

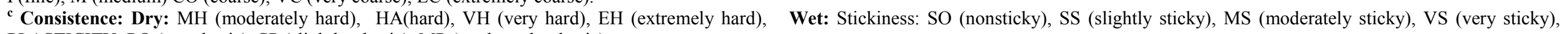
PLASTICITY: PO (nonplastic), SP (slightly plastic), MP (moderately plastic).

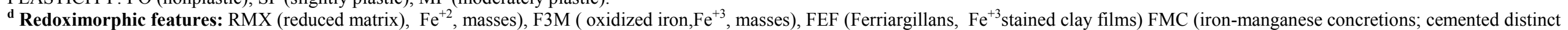
layer), FMN ( iron-manganese nodules, cemented), CLD (clay depletions), FED (iron depletions).

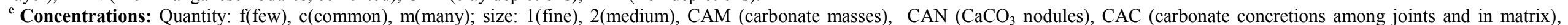

Location: MAT(in the matrix), TOT(throughout), SPO(on surface along pores), RPO (on surface along root channels), CRK (in cracks), TOH (at top of horizon), ARF (around rock fragments).

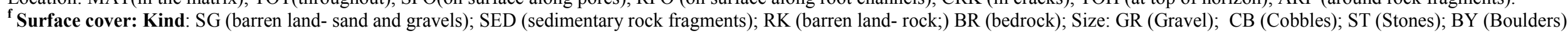




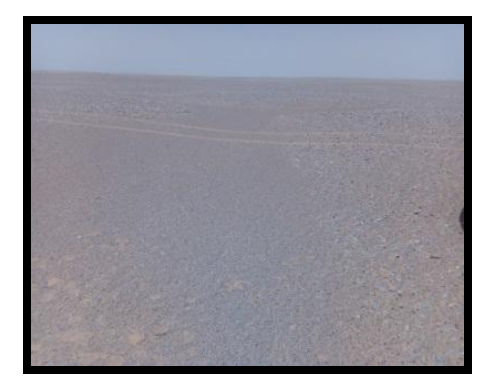

Site view of SMU1

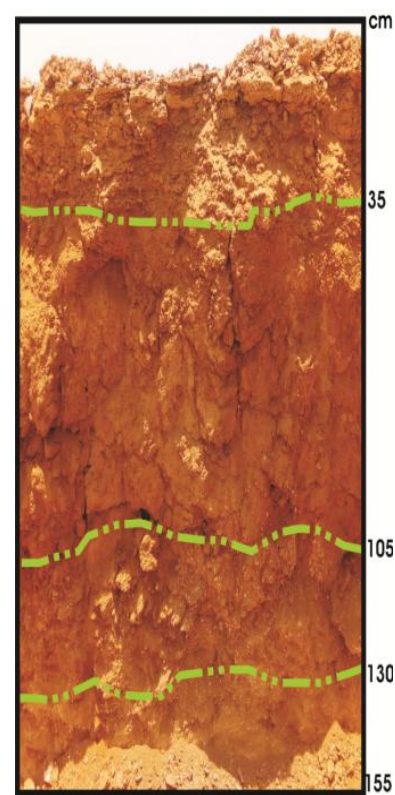

Horizon sequences of pedon 21

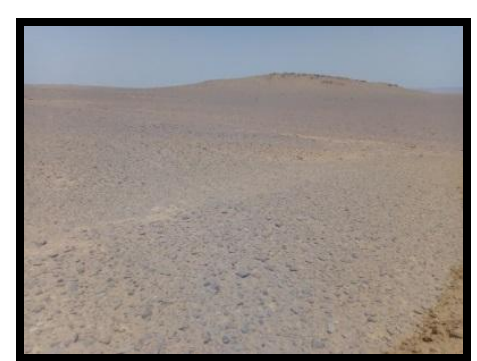

Site view of SMU2

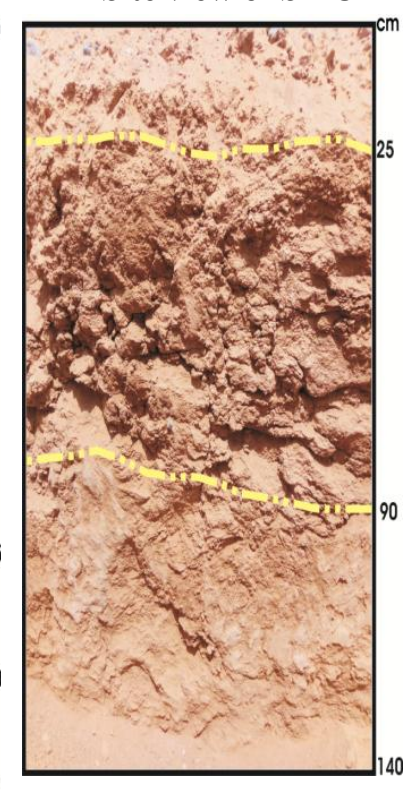

Horizon sequences of pedon 35

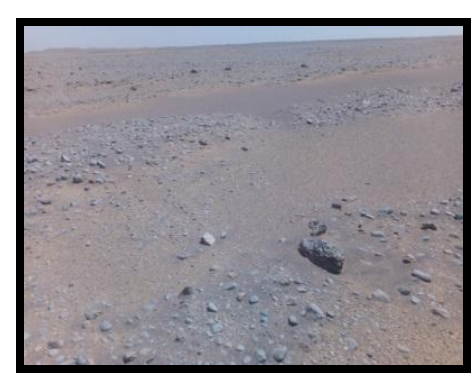

Site view of SMU3

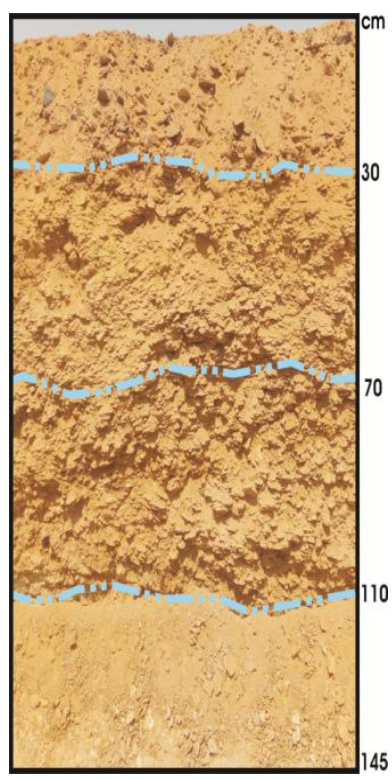

Horizon sequences of SMU2 pedons

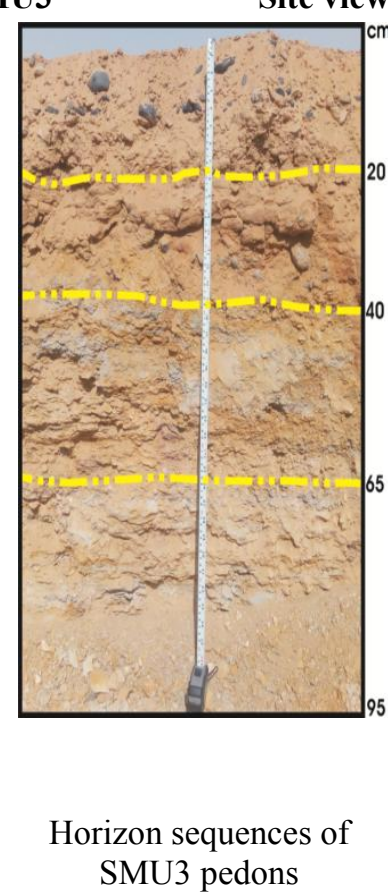

SMU3 pedons

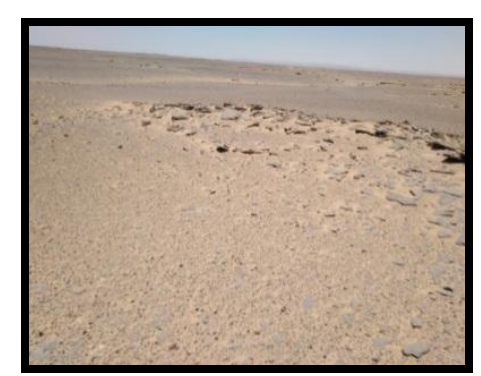

Site view of SMU4

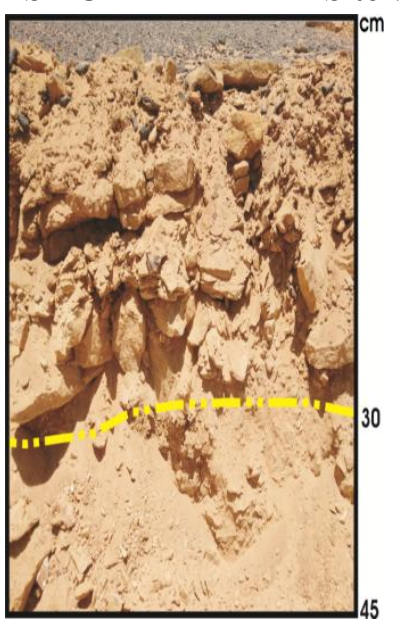

Horizon sequences of SMU4 pedons

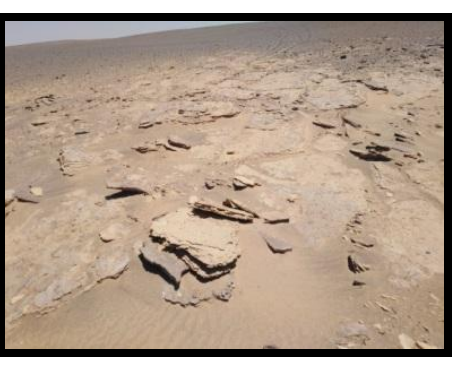

Site view of SMU5

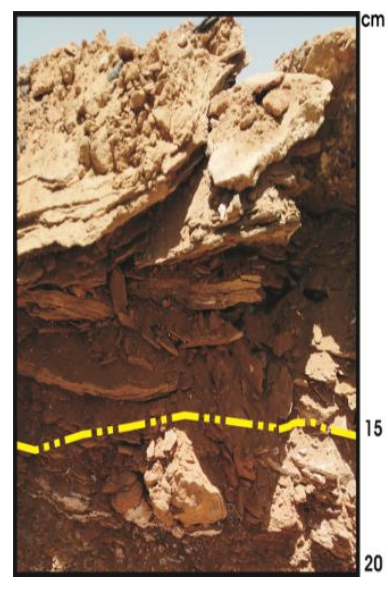

Horizon sequences of SMU5 pedons

Fig. (4): Selected pedons with different layer sequences of SMU4 and SMU5 formed at shoulder slope position. 
Table (3): Physical properties of representative pedons in a toposequence in Wadi El-Amal study area, Aswan

\begin{tabular}{|c|c|c|c|c|c|c|c|c|c|c|}
\hline \multirow{3}{*}{ SMU } & \multirow{3}{*}{$\begin{array}{c}\text { Pedon } \\
\text { No. }\end{array}$} & \multirow{3}{*}{$\begin{array}{l}\text { Depth } \\
\text { interval } \\
\text { (cm) }\end{array}$} & \multirow{3}{*}{$\begin{array}{c}\text { Coarse- } \\
\text { earth } \\
\text { fraction } \\
(\%)\end{array}$} & \multicolumn{6}{|c|}{ Fine-earth fractions (\%) } & \multirow{3}{*}{$\begin{array}{c}\text { A.W. } \\
(\%)\end{array}$} \\
\hline & & & & \multicolumn{3}{|c|}{ Sand } & \multirow[b]{2}{*}{ Silt } & \multirow[b]{2}{*}{ Clay } & \multirow[b]{2}{*}{ Textural class } & \\
\hline & & & & $\begin{array}{c}\text { Coarse } \\
\text { sand }\end{array}$ & $\begin{array}{c}\text { Medium } \\
\text { sand }\end{array}$ & $\begin{array}{l}\text { Fine } \\
\text { sand }\end{array}$ & & & & \\
\hline \multirow{7}{*}{$\begin{array}{c}\text { SMU1 } \\
\text { (Toeslope) }\end{array}$} & \multirow{4}{*}{21} & $0-35$ & 4.15 & 20.75 & 10.25 & 24.25 & 24.25 & 20.5 & Sandy clay loam & 23.55 \\
\hline & & $35-105$ & 3.65 & 5.52 & 3.45 & 7.35 & 50.18 & 33.5 & Silty clay loam & 27.13 \\
\hline & & $105-$ & 6.41 & 4.76 & 16.24 & 9.15 & 32.7 & 37.15 & Clay loam & 30.14 \\
\hline & & $130-$ & 5.64 & 16.68 & 15.87 & 33.25 & 5.1 & 29.1 & Sandy clay loam & 25.35 \\
\hline & \multirow{3}{*}{35} & $0-25$ & 4.08 & 6.65 & 9.15 & 3.45 & 49.83 & 30.92 & Silty clay loam & 28.65 \\
\hline & & $25-90$ & 3.95 & 19.45 & 24.55 & 19.25 & 5.51 & 31.24 & Sandy clay loam & 24.15 \\
\hline & & $90-140$ & 2.07 & 13.66 & 10.25 & 15.24 & 25.17 & 35.68 & Clay loam & 29.15 \\
\hline \multirow{4}{*}{$\begin{array}{c}\text { SMU2 } \\
\text { (Footslope) }\end{array}$} & \multirow{4}{*}{49} & $0-30$ & 15.98 & 8.27 & 2.65 & 49.2 & 28.63 & 11.25 & Sandy loam & 15.95 \\
\hline & & $30-70$ & 19.57 & 10.85 & 9.25 & 21.15 & 35.1 & 23.65 & Loam & 19.25 \\
\hline & & $70-110$ & 21.04 & 7.83 & 5.87 & 11.25 & 54.8 & 20.25 & Silt loam & 17.25 \\
\hline & & $110-$ & 16.18 & 12.44 & 20.66 & 6.45 & 48.8 & 11.65 & Loam & 18.65 \\
\hline \multirow{4}{*}{$\begin{array}{c}\text { SMU3 } \\
\text { (Backslope } \\
\text { ) }\end{array}$} & \multirow{4}{*}{52} & $0-20$ & 20.24 & 34.3 & 13.05 & 35.15 & 12.25 & 5.25 & Loamy sand & 7.05 \\
\hline & & $20-40$ & 17.37 & 41.34 & 21.25 & 27.56 & 2.7 & 7.15 & Coarse sand & 5.36 \\
\hline & & $40-65$ & 16.09 & 45.03 & 18.24 & 25.47 & 1.81 & 9.45 & Loamy sand & 8.45 \\
\hline & & $65-95$ & 15.71 & 20 & 10.25 & 50.25 & 16.05 & 3.45 & Loamy fine sand & 9.15 \\
\hline \multirow{2}{*}{$\begin{array}{c}\text { SMU4 } \\
\text { (Shoulder) }\end{array}$} & \multirow{2}{*}{63} & $0-30$ & 29.18 & 20.19 & 30.05 & 45.21 & 3.3 & 1.25 & Sand & 5.15 \\
\hline & & $30-45$ & 19.44 & 29.24 & 10.77 & 57.35 & 0.49 & 2.15 & Fine sand & 7.36 \\
\hline \multirow{2}{*}{$\begin{array}{c}\text { SMU5 } \\
\text { (Shoulder) }\end{array}$} & \multirow{2}{*}{66} & $0-15$ & 34.25 & 28.62 & 40.29 & 24.54 & 1.99 & 4.56 & Coarse sand & 4.25 \\
\hline & & $15-20$ & 29.38 & 17.51 & 15.14 & 60.24 & 0.64 & 6.47 & Fine sand & 6.45 \\
\hline
\end{tabular}

\section{Soil Chemical Properties}

The results of chemical analyses conducted on soils of Wadi El-Amal are listed in Table (4). The pattern of salinity within the pedon across the study area is related to landscape distribution and slope position. According to Soil Science Division Staff (2017), ECe values were highest for the toeslope soils, ranging from 1.61 to 3.63 $\mathrm{dS} \mathrm{m} \mathrm{m}^{-1}$ (slightly saline) in SMU1. In contrast, lower salinity values $\left(0.38-0.87 \mathrm{dS} \mathrm{m} \mathrm{m}^{-1}\right)$ were recorded in upper slope positions (SMU4 \& SMU5). Consistent with Soil Science Division Staff (2017), pH is alkaline across all studied pedons which varied from 7.93 (moderately alkaline) to 8.98 (strongly alkaline). The vertical distribution of the $\mathrm{pH}$ within each pedon may vary among landscape positions and may either decrease or increase with an increase in depth. SAR values varied from 1.99 to $9.17 \%$ and are not consistent with $\mathrm{pH}$ values in the studied soils.

According to FAO (2006), the results of field and laboratory analysis showed an extremely calcareous character in all native pedons of studied soils with values of $\mathrm{CaCO}_{3}$ ranging from $13.65 \%$ (strongly calcareous) to $39.1 \%$ extremely calcareous (Table 5; Figs. 4, $5 \& 6$ ). $\mathrm{CaCO}_{3}$ values were consistent with the $\mathrm{pH}$ values in all studied soils. The maximum value was recorded in the Cr layers across pedons of SMU4 and SMU5. Lime content was relatively higher in studied soils due to their calcareous nature of the bedrock, as well as leaching of bicarbonate from upper soils during flash flooding and their subsequent precipitation as carbonates in the lower soils. Gypsum concentration across all studied pedons was low (0.07-0.52\%). The irregular trend of $\mathrm{CaCO}_{3}$ and gypsum with depth could be due to the variable nature of the geological materials.

\section{Fertility Status}

Organic matter (O.M) content was found at very low levels which varied from $0.07-0.47 \%$ across the study area (Table 5). The low content was due to poor vegetation and the high rate of organic matter decomposition under hyper-thermic temperature regime which leads to extremely high oxidizing conditions. O.M concentration varies horizontally across the slope position, and vertically within the pedon. It increased strongly downslope and with pedon depth. According to Horneck et al. (2011), the entire soils of the study area had low levels of available nitrogen and phosphorus which varied from 11.1 to $45.83 \mathrm{ppm}$, and 1.64 to 6.89 ppm, respectively. This could be attributed to the low content of organic carbon in these soils and the fixation of released phosphorus by lime and hydroxides of $\mathrm{Ca}$ and $\mathrm{Mg}$. By contrast, available potassium was high $(125.8-275.0 \mathrm{ppm})$ in SMU1 and SMU2 soils and medium (96.3-104.6 ppm) in SMU3. While available potassium concentration in SMU4 and SMU5 was observed in low levels which ranged between 44.21 and $59.12 \mathrm{ppm}$ (Table 5). The distribution of organic matter in these soils was primarily related to physiography and slope location. 
Table (4): Soil chemical characteristics in a catena of Wadi El-Amal study area

\begin{tabular}{|c|c|c|c|c|c|c|c|c|c|c|c|c|c|c|c|}
\hline \multirow{2}{*}{ SMU } & \multirow{2}{*}{$\begin{array}{c}\text { Pedon } \\
\text { ID }\end{array}$} & \multirow{2}{*}{$\begin{array}{c}\text { Horizon } \\
\text { /layer }\end{array}$} & \multirow{2}{*}{$\mathbf{p H}$} & \multirow{2}{*}{$\begin{array}{c}\mathbf{E C}_{\mathrm{e}} \\
\mathrm{dS} / \mathrm{m}\end{array}$} & \multicolumn{4}{|c|}{ Soluble Cations (mg/l) } & \multicolumn{4}{|c|}{ Soluble Anions (mg/l) } & \multirow{2}{*}{$\begin{array}{l}\text { SAR } \\
(\%)\end{array}$} & \multirow{2}{*}{$\begin{array}{c}\mathrm{CaCO}_{3} \\
(\%)\end{array}$} & \multirow{2}{*}{$\begin{array}{c}\text { Gypsum } \\
\text { (\%) }\end{array}$} \\
\hline & & & & & $\mathrm{Na}^{+}$ & $\mathbf{K}^{+}$ & $\mathrm{Ca}^{+2}$ & $\mathrm{Mg}^{+2}$ & $\mathrm{Cl}^{-}$ & $\mathrm{SO}_{4}^{-2}$ & $\mathrm{CO}_{3}^{-2}$ & $\mathrm{HCO}_{3}^{-}$ & & & \\
\hline \multirow{8}{*}{$\begin{array}{l}\text { SMU1 } \\
\text { (Toeslope) }\end{array}$} & \multirow{4}{*}{21} & $\mathrm{C}$ & 7.98 & 2.19 & 14.07 & 0.95 & 4.37 & 2.43 & 15.04 & 4.35 & 0.0 & 2.43 & 7.63 & 25.1 & 0.15 \\
\hline & & $\mathrm{CK}$ & 8.72 & 2.57 & 16.70 & 1.02 & 4.49 & 3.49 & 17.70 & 5.00 & 0.0 & 2.99 & 8.36 & 37.2 & 0.22 \\
\hline & & Ckm & 8.79 & 1.91 & 12.35 & 0.85 & 2.48 & 1.77 & 12.95 & 3.54 & 0.0 & 0.88 & 8.47 & 31.1 & 0.41 \\
\hline & & Ckkm & 7.93 & 1.61 & 10.07 & 0.58 & 3.22 & 2.30 & 10.35 & 3.98 & 0.0 & 1.84 & 6.06 & 27.7 & 0.14 \\
\hline & \multirow{4}{*}{35} & Ap & 8.17 & 2.59 & 16.78 & 0.82 & 6.20 & 3.45 & 17.51 & 6.17 & 0.0 & 3.45 & 7.55 & 23.2 & 0.23 \\
\hline & & $\mathrm{Ck}$ & 8.34 & 3.63 & 22.79 & 1.01 & 7.84 & 4.51 & 24.30 & 8.41 & 0.0 & 3.43 & 9.17 & 25.0 & 0.09 \\
\hline & & Ckkm & 8.90 & 2.78 & 16.98 & 0.85 & 6.05 & 3.49 & 17.25 & 6.72 & 0.0 & 3.39 & 7.77 & 31.1 & 0.18 \\
\hline & & $\mathrm{C}$ & 8.40 & 1.63 & 10.04 & 0.37 & 3.40 & 2.43 & 10.19 & 3.62 & 0.0 & 2.43 & 5.88 & 27.2 & 0.37 \\
\hline \multirow{4}{*}{$\begin{array}{l}\text { SMU2 } \\
\text { (Footslope) }\end{array}$} & \multirow{4}{*}{49} & $\mathrm{Ck}$ & 8.39 & 0.87 & 5.69 & 0.76 & 1.39 & 0.84 & 6.18 & 1.66 & 0.0 & 0.84 & 5.39 & 15.2 & 0.34 \\
\hline & & Ckkm & 8.27 & 0.82 & 5.53 & 0.38 & 1.49 & 0.75 & 5.74 & 1.43 & 0.0 & 0.98 & 5.23 & 17.2 & 0.52 \\
\hline & & $\mathrm{Ckm}$ & 8.24 & 1.91 & 12.45 & 0.85 & 2.45 & 1.79 & 13.99 & 2.53 & 0.0 & 0.85 & 8.41 & 25.25 & 0.24 \\
\hline & & $\mathrm{C}$ & 8.02 & 0.79 & 5.30 & 0.28 & 1.39 & 0.96 & 5.64 & 1.33 & 0.0 & 0.96 & 4.89 & 19.1 & 0.00 \\
\hline \multirow{4}{*}{$\begin{array}{l}\text { SMU3 } \\
\text { (Backslope) }\end{array}$} & \multirow{4}{*}{52} & $\mathrm{Ck}$ & 8.98 & 1.35 & 9.16 & 0.44 & 2.45 & 1.47 & 10.29 & 1.27 & 0.0 & 1.96 & 6.54 & 32.41 & 0.21 \\
\hline & & $\mathrm{Ckm}$ & 7.98 & 1.45 & 9.26 & 0.44 & 2.45 & 1.47 & 10.29 & 1.37 & 0.0 & 1.96 & 6.61 & 22.15 & 0.08 \\
\hline & & $2 \mathrm{C}$ & 8.85 & 2.27 & 14.87 & 0.95 & 4.37 & 2.42 & 15.54 & 4.65 & 0.0 & 2.42 & 8.06 & 33.1 & 0.26 \\
\hline & & $\mathrm{C}$ & 8.05 & 1.73 & 12.25 & 0.85 & 2.45 & 1.72 & 12.94 & 3.50 & 0.0 & 0.83 & 8.48 & 25.7 & 0.17 \\
\hline \multirow{2}{*}{$\begin{array}{l}\text { SMU4 } \\
\text { (Shoulder) }\end{array}$} & \multirow{2}{*}{63} & $2 \mathrm{Cr}$ & 8.78 & 0.74 & 4.54 & 0.80 & 1.24 & 0.84 & 4.69 & 1.74 & 0.0 & 0.99 & 4.45 & 22.1 & 0.11 \\
\hline & & $\mathrm{Cr}$ & 8.94 & 0.86 & 5.54 & 0.38 & 1.69 & 0.99 & 6.04 & 1.57 & 0.0 & 0.99 & 4.79 & 33.9 & 0.27 \\
\hline \multirow{2}{*}{$\begin{array}{l}\text { SMU5 } \\
\text { (Shoulder }\end{array}$} & \multirow{2}{*}{66} & $\mathrm{R}$ & 8.09 & 0.38 & 1.81 & 0.23 & 0.95 & 0.81 & 1.90 & 1.18 & 0.0 & 0.71 & 1.99 & 39.1 & 0.07 \\
\hline & & $\mathrm{C}$ & 8.17 & 0.87 & 5.69 & 0.76 & 1.39 & 0.84 & 6.18 & 1.66 & 0.0 & 0.84 & 5.39 & 13.65 & 0.31 \\
\hline
\end{tabular}


The studied micronutrients consist of four essential elements: iron $(\mathrm{Fe})$, manganese $(\mathrm{Mn})$, zinc $(\mathrm{Zn})$, and copper $(\mathrm{Cu}$. These elements occur in very small amounts in both soils and plants, but their role is equally as important as the primary or secondary nutrients. On the basis of critical limits of available micronutrients given by Jacobsen et al. (2005) and Horneck et al. (2011), the studied soils of SMU1, SMU2, and SMU3 were marginal to adequate in available iron, manganese, zinc, and copper. Micronutrient cations of Fe, Mn, Zn, and $\mathrm{Cu}$ in these soils ranged from 3.83 to $7.49 \mathrm{ppm}$, 1.48-3.44 ppm, 0.74-2.44 ppm, and 0.54-1.76 ppm, respectively (Table 5). By contrast, other soils of SMU 3 and SMU 4 were very low to low in these nutrients, where they ranged from 0.91 to $2.45 \mathrm{ppm}$ for $\mathrm{Fe}, 0.12$ $0.39 \mathrm{ppm}$ for $\mathrm{Mn}, 0.19-0.38 \mathrm{ppm}$ for $\mathrm{Zn}, 0.06-0.13 \mathrm{ppm}$ for $\mathrm{Cu}$ (Table 5). Low available micronutrients in the soils may be attributed to high soil $\mathrm{pH}$ and the calcareous content observed and could react with $\mathrm{Ca}^{++}$ and $\mathrm{Mg}^{++}$cations or $\mathrm{CaCO}_{3}$ to produce insoluble compounds that are not readily available for plant uptake (Hodges, 2007). A deficiency of one or more of the micronutrients can lead to severe depression in growth, yield, and crop quality. Soils of SMU3 and SMU4 do not contain sufficient amounts of these nutrients to meet the plant's requirements for rapid growth and good production. Therefore, supplemental micronutrient applications in the form of commercial fertilizers or foliar sprays must be made. Chemical fertilizer application should be in small, regular rates that are applied close to plant roots as sandy soils have the very little capacity to hold large concentrations of nutrients. Addition of organic matter levels can help to reduce any micronutrient 'fixation' reactions that may be present, by binding $\mathrm{Ca}^{++}$and $\mathrm{Mg}^{++}$, and forming soluble complexes which may be available to plants (Hodges, 2007). CEC varied from $3.17 \mathrm{cmol}(+) \mathrm{kg}^{-1}$ ) in studied pedons at upper slope positions in SMU5 to $27.45 \mathrm{cmol}(+) \mathrm{kg}^{-1}$ ) at lower slope position in SMU1 (Table 5). This showed that the soils of SMU4 and SMU5 have low nutrient retention capacity. CEC values were highly concomitant with O.M and clay content horizontally across toposequence and vertically within pedons. The CEC values indicate the fertility potential in soil of SMU1 at toeslope compared with that of upland at back slope and shoulder slope positions. Low CEC levels in the studied soils at shoulder position may also be due to heavy base leaching down the pedons, as well as the soil's very low clay content.

Table (5): Nutrient and fertility status of the investigated soils across the studied soil mapping units

\begin{tabular}{|c|c|c|c|c|c|c|c|c|c|c|c|}
\hline \multirow{2}{*}{ SMU } & \multirow{2}{*}{$\begin{array}{l}\text { Pedon } \\
\text { No. }\end{array}$} & \multirow{2}{*}{$\begin{array}{l}\text { Horizon } \\
\text { /layer }\end{array}$} & \multirow{2}{*}{$\begin{array}{c}\text { O.M } \\
(\%)\end{array}$} & \multicolumn{7}{|c|}{ Available macro and micronutrients, ppm } & \multirow{2}{*}{ 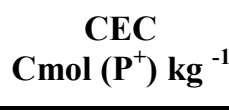 } \\
\hline & & & & $\mathbf{N}$ & $\mathbf{P}$ & $\mathbf{K}$ & $\mathbf{F e}$ & Mn & Zn & $\mathbf{C u}$ & \\
\hline \multirow{7}{*}{$\begin{array}{l}\text { SMU1 } \\
\text { (Toeslope) }\end{array}$} & \multirow{4}{*}{21} & $\mathrm{C}$ & 0.20 & 44.02 & 6.89 & 193.6 & 4.59 & 2.14 & 1.52 & 1.76 & 25.95 \\
\hline & & $\mathrm{CK}$ & 0.28 & 39.83 & 5.42 & 215.0 & 5.69 & 3.44 & 1.33 & 1.11 & 19.18 \\
\hline & & $\mathrm{Ckm}$ & 0.47 & 43.02 & 5.93 & 228.4 & 4.16 & 1.91 & 1.16 & 0.72 & 27.45 \\
\hline & & Ckkm & 0.14 & 45.83 & 6.14 & 275.0 & 4.56 & 2.04 & 1.51 & 1.20 & 21.45 \\
\hline & \multirow{3}{*}{35} & Ap & 0.40 & 41.70 & 5.66 & 244.4 & 6.17 & 1.95 & 1.71 & 1.07 & 26.48 \\
\hline & & $\mathrm{Ck}$ & 0.27 & 45.90 & 6.88 & 229.4 & 5.56 & 2.74 & 1.09 & 0.82 & 24.25 \\
\hline & & Ckkm & 0.31 & 39.17 & 5.45 & 235.5 & 7.49 & 2.12 & 1.41 & 1.09 & 25.86 \\
\hline \multirow{4}{*}{$\begin{array}{l}\text { SMU2 } \\
\text { (Footslope) }\end{array}$} & \multirow{4}{*}{49} & $\mathrm{C}$ & 0.44 & 31.3 & 6.33 & 134.2 & 3.72 & 1.50 & 1.91 & 0.94 & 14.08 \\
\hline & & $\mathrm{Ck}$ & 0.20 & 35.20 & 4.60 & 125.8 & 4.20 & 1.89 & 1.63 & 0.85 & 16.05 \\
\hline & & Ckkm & 0.29 & 25.80 & 2.65 & 136.5 & 3.98 & 1.48 & 1.41 & 0.58 & 15.09 \\
\hline & & $\mathrm{Ckm}$ & 0.14 & 34.91 & 2.51 & 173.1 & 4.34 & 1.56 & 2.44 & 1.53 & 13.89 \\
\hline \multirow{4}{*}{$\begin{array}{l}\text { SMU3 } \\
\text { (Backslope) }\end{array}$} & \multirow{4}{*}{52} & $\mathrm{C}$ & 0.27 & 22.70 & 4.84 & 98.2 & 4.78 & 1.80 & 0.91 & 1.02 & 7.68 \\
\hline & & $\mathrm{Ck}$ & 0.23 & 31.00 & 2.92 & 96.3 & 3.90 & 1.58 & 1.42 & 0.74 & 6.09 \\
\hline & & $\mathrm{Ckm}$ & 0.11 & 37.10 & 1.64 & 104.6 & 3.83 & 1.64 & 0.74 & 0.74 & 6.24 \\
\hline & & $2 \mathrm{C}$ & 0.20 & 20.40 & 3.39 & 101.9 & 4.35 & 1.70 & 1.32 & 0.59 & 5.36 \\
\hline \multirow{2}{*}{$\begin{array}{l}\text { SMU4 } \\
\text { (Shoulder) }\end{array}$} & \multirow{2}{*}{63} & $\mathrm{C}$ & 0.10 & 19.74 & 1.65 & 55.23 & 2.45 & 0.39 & 0.22 & 0.13 & 4.25 \\
\hline & & $2 \mathrm{Cr}$ & 0.02 & 17.21 & 2.35 & 59.12 & 2.08 & 0.51 & 0.19 & 0.06 & 3.08 \\
\hline \multirow{2}{*}{$\begin{array}{l}\text { SMU5 } \\
\text { (Shoulder) }\end{array}$} & \multirow{2}{*}{66} & $\mathrm{Cr}$ & 0.07 & 11.10 & 3.20 & 44.21 & 2.15 & 0.32 & 0.38 & 0.07 & 5.32 \\
\hline & & $\mathrm{R}$ & 0.07 & 13.50 & 1.87 & 45.35 & 0.91 & 0.12 & 0.20 & 0.09 & 3.17 \\
\hline
\end{tabular}




\section{Land Evaluation of Wadi El-Amal Area}

Based on the characteristics of water, soil, environment, and socioeconomic and political collections, the interpretative groupings of land evaluation methods (QL $\mathrm{Q}_{\mathrm{L}} \mathrm{DLE}$, USDA LCC, and $\mathrm{Q}_{\mathrm{L}} \mathrm{DLAC}$ ) were carried out as presented in Table (6) and Figs. (5 and 6). The agricultural limitations were identified for each soil mapping unit. Irrigation water is available with good quality, low aggregated soil limitations, and good status of socioeconomic measures; besides the political factors which support the development of SMU1 and SMU2. Despite the high content of gravel in footslope soils, it couldn't be considered a severe limitation for crop production. Slightly salinity and highly lime content at specific locations at toeslope were the slight limitations of the area which can be improved by specific management. As a result, the $\mathrm{Q}_{\mathrm{L}} \mathrm{DLPE}$ index has placed the SMU1 and SMU2 in high potential classes to produce a wide range of crops (Table 6 and Fig. 5). Meanwhile, irrigation water is available but with permissible conditions at the area of SMU3 that is why the $\mathrm{Q}_{\mathrm{L}} \mathrm{DLPE}$ index placed these resources in slight potential class.

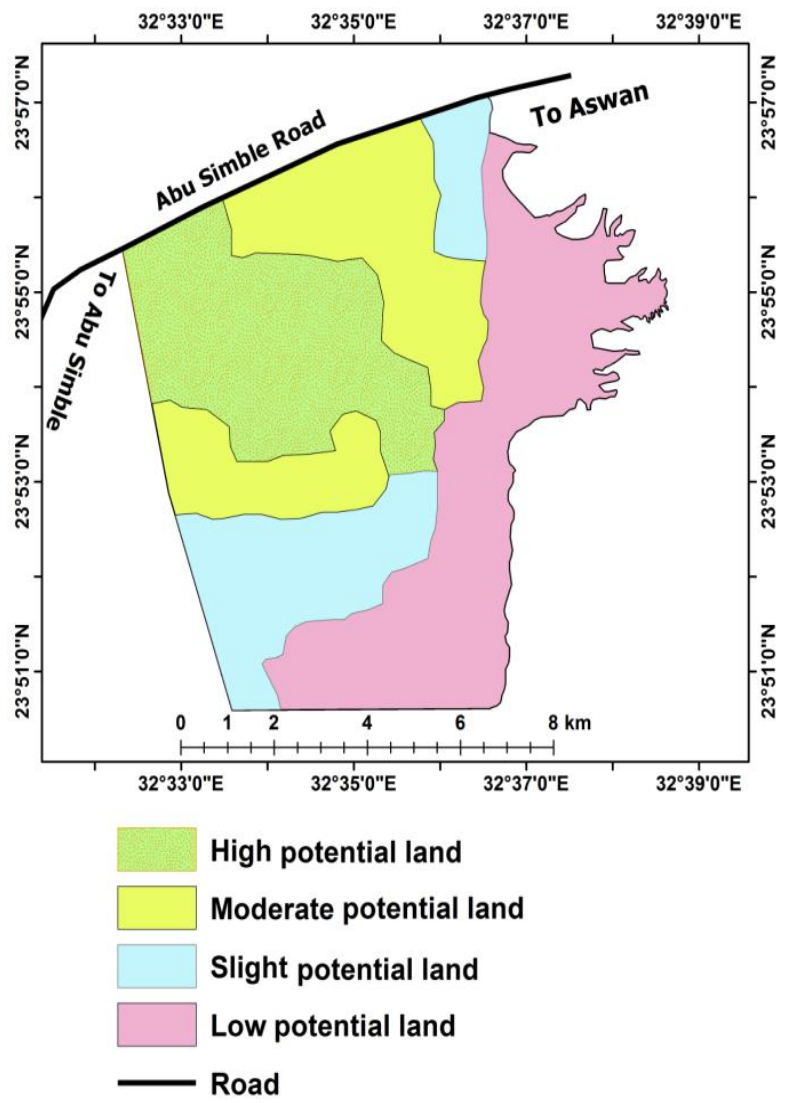

Fig. (5): Land potentiality classes of Wadi El-Amal study area using $\mathrm{Q}_{\mathrm{L}} \mathrm{DLPE}$ model

Among salient soil limitations, shallower depth, somewhat poorly drainage, coarse fragments either on the surface of the land or within pedon layers, high content of lime, and low in fertility status as well as the undulating topography were found to be the most important constraints for agricultural development in the area of SMU4 and SMU5. Consequently, lands occupied on the shoulder were placed under low potentiality class based on $\mathrm{Q}_{\mathrm{L}} \mathrm{DLPE}$ method. Soils of SMU5 with very severe limitations owing to undulating topography, soil erosion hazard, the very shallowness of soil depth, poor drainage, coarse fragments severe limitations of soil erosion, poor infrastructure, lack of technical knowledge, and weak institutional support made up the $\mathrm{Q}_{\mathrm{L}} \mathrm{DLPE}$ index low which placed under low potentiality classes (Table 6 and Fig. 5). The low potential land is not sufficient to grow crops in a profitable way. Thus, the non-agricultural activities are recommended for the midland area; e.g., road construction to link the lower portions (toeslope) of the Wadi to its upper portion (shoulder).

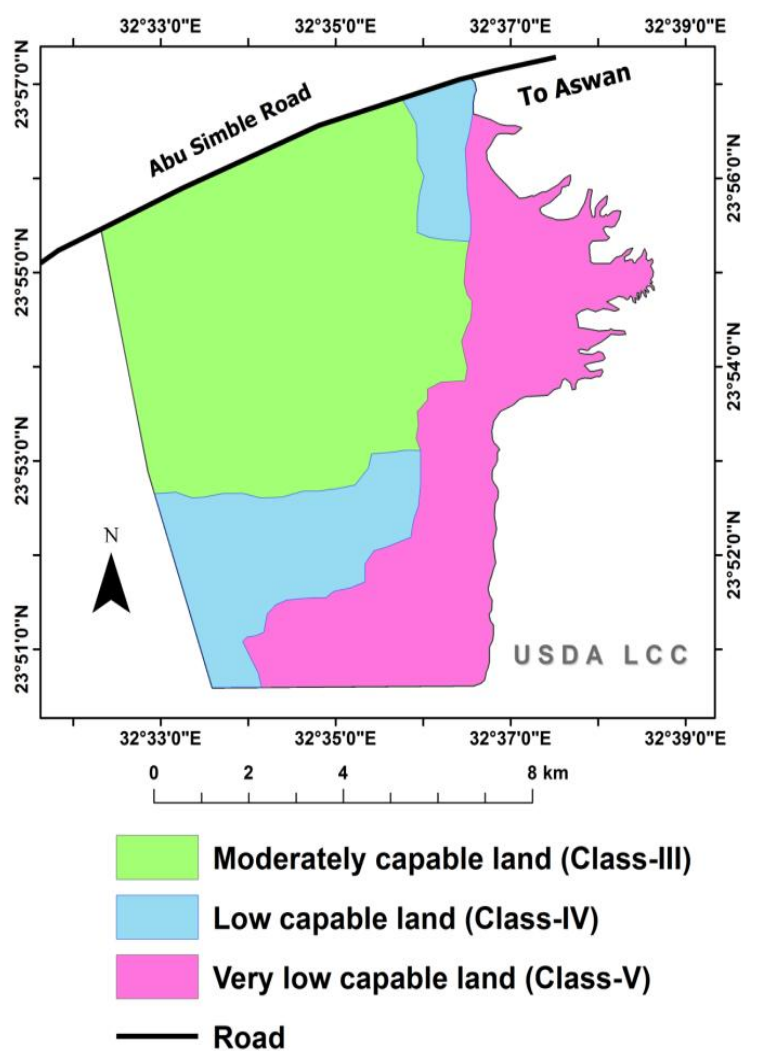

Fig. (6): Land capability classes of Wadi El-Amal study area using the American land capability classification method

Accordingly, the land under study could be categorized as per $\mathrm{Q}_{\mathrm{L}} \mathrm{DLPE}$ model into four potentiality classes (Fig. 5). Around 4760 Faddan (24.64\%) was found to have high potential land. This area is entirely covered by the soils of SMU1. Moderate potential class was for SMU2 which occupy an area of 4740 Faddan. In contrast, slight potential lands were for SMU3 (3350 Faddan) and low potential class covered an area of 6470 Faddan (33.49\%) and distributed on SMU4 (2900 Faddan) and SMU5 (3570 Faddan) (Table 6 and Fig. 5). On the other hand, USDA LCC system has grouped the studied lands into three capability classes (Table 6 and Fig. 8). The moderately capable lands (Class III) represent $49.17 \%$ of the total area; it is associated with the soils of SMU1 and SMU2. Low capable lands cover $17.34 \%$ of the study area (3350 Faddan) which represented by SMU3. Lands of SMU4 and SMU5 had very low capable classes; these units represent $33.49 \%$ of the total area (6470 Faddan). 
Based on the climate, soil physical (Table 3), chemical characteristics (Table 4), and fertility data (Table 5), interpretative groupings of $\mathrm{Q}_{\mathrm{L}} \mathrm{DLAC}$ were worked out for agricultural priority as presented in Table (6). The criteria of climate, environment, soil, and agricultural policies were determined and matched with the optimum crop requirements for different strategic crops. The affecting limitations were regarding climate, limited irrigation water, land topography, shallow soils, sandy texture, high contents of gravel and coarse fragments, soil salinity, $\mathrm{pH}, \mathrm{CaCO}_{3}$, soil available water, soil drainage, and poor fertility. Additionally, agricultural policies criteria for priority crops were considered as suggested by the Egyptian government in respect to marketing responses achieving selfsufficiency in this area. Precision farming technology interventions in soil and water management, as well as crop enhancement, are expected to result in high agricultural output for adapting to the local conditions of the studied region (Tohidyan and RezaeiMoghaddam, 2018).

Accordingly, six land utilization types (LUTs) were tested for their aptness in the studied soils. Four different classes of land aptness (high, moderate, slight, and non-aptness) were separately given for each crop based on the intensity of significant limitations. Only the high aptness crops were suggested to be cultivated in the mapped soils (Table 6). These crops were prioritized over the study area as optimum land utilization types (LUTs) for profitable cultivation based on the high market value. They are: (i) field crops (sugar beet, cassava, quinoa, wheat, barley, and maize); (ii) vegetables (tomatoes, cucumber, peppers, potatoes, pea, soybean, squash, and onion); (iii) citrus-fruits such as mango, datepalm, olive, lemon, and grape; (iv) oil crops (sesame, canola, jojoba, and jatropha) were suggested for achieving self-sufficiency in edible oil and biofuel; (v) forages (sorghum, panicum, and alfalfa) were selected as alternatives for livestock fodders to be cultivated in SMU3; and (vi) medicinal and aromatic plants (coriander, mint, senna, and rose) (Table 6).

\section{Land Use Planning of Study Area}

On the basis of the previous results of land evaluation procedures, the IDLUP methodology has decided and outlined in Table (6) and presented in Fig. (7). Based on the value-added for crops, the priority order for agrarian expansion was determined and suggested for all crops. As per IDLUP model, the studied lands were planned into two main groups which are: (a) planning for agricultural development, and (b) planning for non-agricultural development. The agrarian expansion should be divided into equal pieces to achieve the precision farming in a sustainable basis. The priority order for agricultural development was based on the addition value of crops. The value-added crops were selected as land utilization types and prioritized as follows: field crops and vegetables (4760 Faddan) > citrus-fruits and oil crops (4740 Faddan) $>$ medicinal and aromatic plants and forages (3350 Faddan). For optimum land use planning of the study area, lands of SMU4 and SMU4 which occupy 6470 Faddan (33.49\%) were excluded from the agricultural development.
Henceforth, the priorities of land utilization planning were categorized into four priorities as follows:

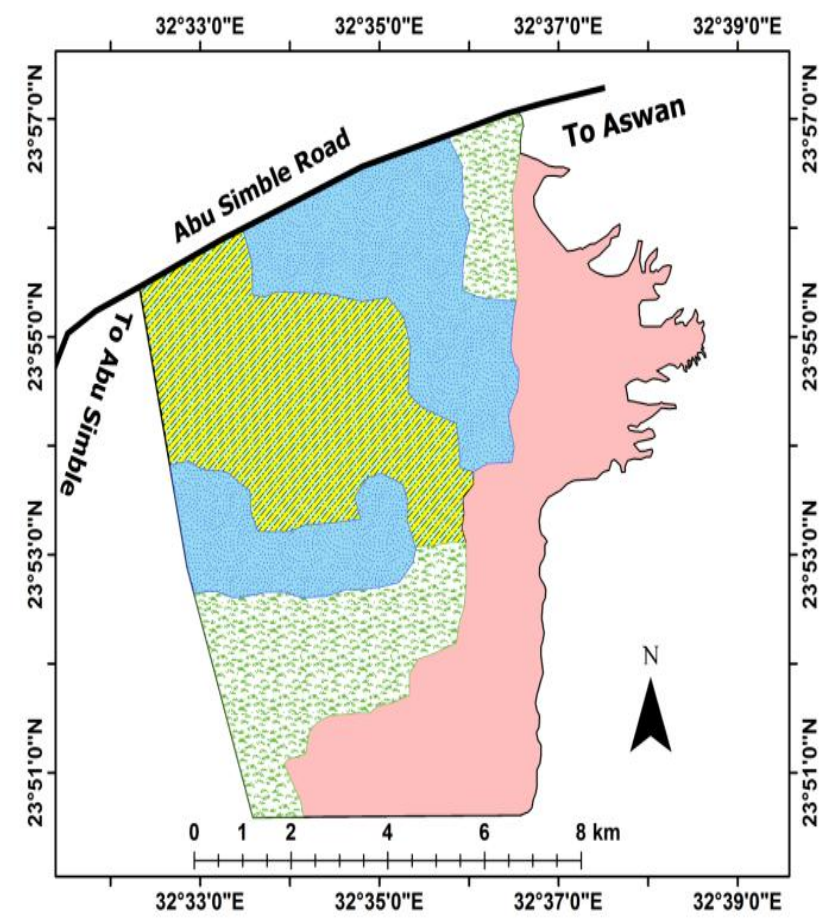

Planning for Agricultural Development:

First priority for field crops and vegetables

Second priority for citrus-fruits and oil crops

Third priority for forages and aromatic plants

Planning for Non-agricultural Development:

Fourth priority for housing and constructions

- Road

Fig. (7): Integrated planning of Wadi El-Amal area for sustainable development

\section{First priority for field crops and vegetables:}

High potentiality lands (4760 Faddan) (Fig. 4) must always come as the first priority for sustainable protected agriculture (Fig. 7). Soils belonging to this group have got the potential function to produce rich and cash vegetables through greenhouse technologies overcoming the environmental risks (Fig. 7). Egypt is a net food importer, including for over half of its wheat needs. To achieve the food security, the self-sufficiency of strategic and food crops in the studied region must be done by increasing their production per unit by following the priority pattern (wheat $>$ sugar beet $>$ cassava $>$ quinoa $>$ maize $>$ barley).

\section{Second priority for citrus-fruits and oil crops:}

The high value-added crops such as Oil crops and citrus-fruits were selected to be the second priority for cultivation in SMU2 (4740 Faddan). Soils belonging to this group have got moderate potential function to produce these crops in profitable basis. The agrarian expansion in this area is based on the following priority pattern: jojoba $>$ canola $>$ sesame $>$ olive $>$ datepalm $>$ mango $>$ lemon $>$ peach $>$ grape. 


\section{Third priority for aromatic plants and forages:}

Slight potential land which occupies 3350 Faddan on SMU3 was proposed for the third priority for precision farming using aromatic plants and forages in profitable way. Based on the value-added for these crops, the priority order for agrarian expansion was determined as follows: rose $>$ coriander $>$ senna $>$ mint $>$ panicum $>$ alfalfa $>$ sorghum $>$ clover.

\section{Fourth priority for housing and constructions:}

The area of SMU4 and SMU5 was excluded from the agricultural activities. This area (6470 Faddan) is suitable for non-agricultural activities such as housing, new towns, urban settlements, and industries. New smart Abu-Simble city is suggested to be constructed in the area of SMU4 which extends on 2900 Faddan. The new city should include all the services such as hospital, schools, university, club, and other governmental institutions. The roads should be constructed first to link the soil mapping units with the Abu-Simble road. The industries, museum, and other related tourism activates should be established in the area of SMU5 which extends on 3570 Faddan.

Table (6): Land evaluation classes and suggested planning priorities across soil mapping units

\begin{tabular}{|c|c|c|c|c|c|}
\hline \multirow{2}{*}{$\mathbf{S M U}^{\mathbf{a}}$} & \multirow{2}{*}{$\underset{\text { class }^{b}}{\mathrm{Q}_{\mathrm{L}} \mathrm{DLPE}}$} & \multirow{2}{*}{$\begin{array}{l}\text { USDA } \\
\mathrm{LCC}^{\mathrm{c}}\end{array}$} & \multirow{2}{*}{$\frac{\mathrm{Q}_{\mathrm{L}} \text { DLAC }^{\mathrm{d}}}{\text { High aptness LUTs }}$} & \multicolumn{2}{|l|}{ IDLUP $^{\mathrm{e}}$} \\
\hline & & & & $\begin{array}{c}\text { Planning and priority } \\
\text { pattern }\end{array}$ & $\begin{array}{c}\text { Areal } \\
\text { coverage }\end{array}$ \\
\hline SMU1 & $\mathbf{H}$ & \multirow[t]{2}{*}{ Class-III } & $\begin{array}{l}\text { LUT1 (Field crops): wheat, } \\
\text { cassava, quinoa, barley, } \\
\text { maize, sugar beet. } \\
\text { LUT2 (Vegetables): } \\
\text { tomatoes, cucumber, } \\
\text { potatoes, peppers, soybean, } \\
\text { onion, and squash. }\end{array}$ & $\begin{array}{l}\text { Precision farming: } \\
1^{\text {st }} \text { priority for wheat }>\text { sugar } \\
\text { beet }>\text { cassava }>\text { quinoa }> \\
\text { maize }>\text { barley }>\text { tomatoes }> \\
\text { potatoes }>\text { peppers }> \\
\text { soybean }>\text { cucumber }> \\
\text { squash }>\text { onion. }\end{array}$ & $\begin{array}{c}4760 \\
\text { Faddan } \\
(24.64 \%)\end{array}$ \\
\hline SMU2 & $\mathbf{M}$ & & $\begin{array}{l}\text { LUT3 (Citrus-fruits): grape, } \\
\text { olive, datepalm, mango, } \\
\text { peach, lemon } \\
\text { LUT4 (Oil crops): jatropha, } \\
\text { jojoba, canola, sesame. }\end{array}$ & $\begin{array}{c}\text { Precision farming: } \\
2^{\text {st }} \text { priority for jatropha }> \\
\text { jojoba }>\text { canola }>\text { sesame }> \\
\text { olive }>\text { datepalm }>\text { mango }> \\
\text { lemon }>\text { peach }>\text { grape. }\end{array}$ & $\begin{array}{c}4740 \\
\text { Faddan } \\
(24.53 \%)\end{array}$ \\
\hline SMU3 & $\mathbf{S}$ & Class-IV & $\begin{array}{l}\text { LUT5 (Forages): panicum, } \\
\text { alfalfa, sorghum. } \\
\text { LUT6 (Medicinal and } \\
\text { aromatic plants): rose, } \\
\text { coriander, senna, mint. }\end{array}$ & $\begin{array}{c}\text { Precision farming: } \\
3^{\text {st }} \text { priority for rose }> \\
\text { coriander }>\text { senna }>\text { mint }> \\
\text { panicum }>\text { alfalfa }> \\
\text { sorghum. } \\
\end{array}$ & $\begin{array}{c}3350 \\
\text { Faddan } \\
(17.34 \%)\end{array}$ \\
\hline $\begin{array}{l}\text { SMU4 } \\
\text { SMU5 }\end{array}$ & $\mathbf{L}$ & Class-V & Non-productive lands. & $\begin{array}{c}\text { Non-agricultural land: } \\
4^{\text {st }} \text { priority for housing and } \\
\text { constructions. }\end{array}$ & $\begin{array}{c}6470 \\
\text { Faddan } \\
(33.49 \%) \\
\end{array}$ \\
\hline \multicolumn{6}{|c|}{$\begin{array}{l}{ }^{a} \text { SMU (soil mapping unit) } \\
{ }^{\mathrm{b}} \mathrm{Q}_{\mathrm{L}} \text { DLPE (Qualitative desert land potentiality evaluation), H (high potential land), M (moderate potential land), S (slight potential } \\
\text { land), L (low potential land) } \\
{ }^{\mathrm{C}} \text { USDA-LCC (USDA Land capability classification), Class-III (moderately capable land, Class-IV (low capable land), Class-V (very } \\
\text { low capable land) } \\
{ }^{\mathrm{d}} \text { LUT (land utilization type) } \\
{ }^{\mathrm{e}} \text { IDLUP: Integrated desert land use planning }\end{array}$} \\
\hline
\end{tabular}

\section{CONCLUSION}

This work incorporates evaluation of all aspects related to soil, water, climate, socioeconomic measures in the desert ecosystem of Wadi El-Amal area, Aswan, Egypt. Specialized desert land use planning approaches attempted in the present study can be better tools for optimizing desert land use on a sustained basis. $\mathrm{Q}_{\mathrm{L}} \mathrm{DLPE}$ model has grouped the study area into four potentiality classes while the USDA LCC system classified the study area into three capability classes. $\mathrm{Q}_{\mathrm{L}} \mathrm{DLAC}$ has suggested six land utilization types as value-added crops for cultivation in the study area. IDLUP has planned an area of about of $66.51 \%$ of the total study area (12850 Faddan) for agricultural development and excluded the rest area (33.49\%) from the agrarian expansion which may be used for the housing and constructions. The value-added crops in the agrarian expansion area were prioritized as follows: field crops and vegetables (4760 Faddan) $>$ citrus-fruits and oil crops (4740 Faddan) $>$ medicinal and aromatic plants and forages (3350 Faddan).If these suggested measures are adopted correctly, it would help to reduce desertification process in the study area. These measures could also reduce the severity of drought and increase the agricultural productivity. The methodology presented in this paper could be very helpful to meet the target of zero hunger. This methodology including $\mathrm{Q}_{\mathrm{L}}$ DLPE, USDA LCC, Q Q DLAC, and IDLUP can be easily incorporated in GIS domain and could be applied to local, regional and national scales in desert regions. This integrated methodology can also be applied elsewhere to ensure sustainable food production systems and to progressively improve land and soil quality. 


\section{REFERENCES}

Alary, V., A. Aboul-Naga, M. A. Osman, I. Daoud, S. Abdelraheem, E. Salah, J. Xavier and B. Pascal (2018). Desert land reclamation programs and family land dynamics in the Western Desert of the Nile Delta (Egypt), 1960-2010. World Development, 104: 140-153

ASRT (1982). Soil Map of Egypt - Final Report. Academy of Scientific Research and Technology, Cairo, Egypt.

Ayres, R. S. and D. W. Westcott (1976). Water quality for agriculture. F.A.O. Irrigation and Drainage Paper No. 29 F.A.O. Rome.

Central agency for public mobilization and Statistics of Egypt (2020). Egypt Statistical Yearbook 2016. Issue No. 108. Ref., No. 71: 01111-2016.

Corato, L. D. and M. V. Brady (2019). Passive farming and land development: A real options approach, Land Use Policy, 80: 32-46.

Egyptian Meteorological Authority (2020). Climatic Atlas of Egypt - Asawn meteorological station, Cairo, Egypt.

Ellili-Bargaoui, Y., C. Walter, D. Michot and B. Lemercier (2020). Mapping soil properties at multiple depths from disaggregated legacy soil maps in the Brittany region, France, Geoderma Regional, 23: e00342.

El-Shazly, E. M. (1977). The Geology of the Egyptian Region, 193-207 pp.

Elwan, A. A. (2013). Novel approaches of land evaluation using geospatial technologies for planning sustainable development of desert areas. Ph.D. (Ag) Thesis, Tamil Nadu Agric. Univ., Coimbatore, India.

Elwan, A. A. (2019). Dry Lands, Biodiversity, Management, and Conservation. LC ebook Chapter No. 9: Proper Evaluation of Desert Ecosystem for Sustainable Development. Environmental Reasearch Advances. Nova Science Publishers, Inc., New York.

Elwan, A. A. and R. Sivasamy (2013a). Inadequacy of existing land evaluation systems for desert regions development. Zagazig J. Agric. Res., 40(1): 49-57.

Elwan, A. A. and R. Sivasamy (2013b). Novel approach of land evaluation for natural resource management of desert ecosystem. Agricultural Graduate Student Conference on Food Safety and Food Security. Madras Agric. J., 100: 156-164.

Emmet-Booth, J. P., P. D. Forristal, O. Fenton, G. Bondi and N. M. Holden (2019). Visual soil evaluation - Spade vs. profile methods and the information conveyed for soil management, Soil \& Tillage Research, 187: 135-143.

FAO (1970). Physical and Chemical Methods of Soil and Water Analysis. Soils Bulletin No.10. FAO, Rome, Italy.

FAO (2006). Guidelines for Soil Description. $4^{\text {th }}$ Edition. Food and Agriculture Organization of the United Nations, Rome, Italy.
Gaber, A., F. Khalaf, M. Bastawisy and F. El-Baz (2018). Combining satellite image data and field observations to characterize fresh-water carbonates in Kurkur Oasis, Southern Egypt, Journal of African Earth Sciences, 139: 193-204.

Gad, A. (2015). Land capability classification of some western desert Oases, Egypt, using remote sensing and GIS. The Egyptian Journal of Remote Sensing and Space Sciences, 18: S9S18.

Helms, D. (1992). Reading in the history of the soil conservation service. US Government Printing Office, Washington, DC, 60-73.

Hodges, S. C. (2007). Soil Fertility Basics. Soil Science Extension North Carolina State University.

Horneck, D. A., D. M. Sullivan, J. S. Owen and J. M. Hart (2011). Soil Test Interpretation Guide. Oregon State University, EC 1478-E.

Issawi, B. (1978). Geology of Nubia west area, western desert, Annals of the Geological Survey of Egypt.

Itichaa, B. and C. Takeleb (2019). Digital soil mapping for site-specific management of soils. Geoderma, 351: 85-91.

Jackson, M. L. (1973). Soil Chemical Analysis. Advanced course. $2^{\text {nd }}$ ed. A Manual of Methods Useful for Instruction and Research in Soil Chemistry, Physical Chemistry of Soil, Soil Fertility, and Soil Genesis. U.S.A.

Jacobsen, J., G. Jackson and C. Jones (2005). Fertilizer Guidelines for Montana Crops. Montana State University Extension: Bozeman, MT. EB 161.

Juhos, K. and B. Madarāsz (2016). Interpretation and integration of pedological data in land evaluation systems. Bulgarian J. Agricultural Sci., 22(2): 209-215.

Klingebiel, A. A. and P. H. Montgomery (1973). Land Capability Classification, Agriculture Handbook No. 210, Soil Conservation Service, U.S. Department of Agriculture, USA.

Kuang, W., J. Liua, J. Dong, W. Chi and C. Zhang (2016). The rapid and massive urban and industrial land expansions in China between 1990 and 2010: A CLUD-based analysis of their trajectories, patterns, and drivers. Landscape and Urban Planning, 145: 21-33.

Lindsay, W. L. and W. A. Norvell (1978). Development of DTPA soil test for zinc, iron, manganese and copper. Soil Sci. Soc. Am. J., 42: 421-428.

Mani, A. K., R. Santhi and K. M. Sellamuthu (2007). A Handbook of Laboratory Analysis. $1^{\text {st }}$ edition. ISBN: 978-81-902558-8-2, A.E. Publications, Coimbatore, Tamil Nadu, India.

Moonjun, R., D. P. Shrestha and V. G. Jetten (2020). Fuzzy logic for fine-scale soil mapping: A case study in Thailand, Catena, 190: 104456.

Moragues-Quiroga, C., J. Juilleret, L. Gourdol, E. Pelt, T. Perrone, A. Aubert, G. Morvan, F. Chabaux, A. Legout, P. Stille and C. Hissler (2017). 
Genesis and evolution of regoliths: Evidence from trace and major elements and $\mathrm{Sr}-\mathrm{Nd}-\mathrm{Pb}-\mathrm{U}$ isotopes. Catena, 149: 185-198.

Page, A. L., R. H. Miller and D. R. Keeney (1982). Methods of Soil Analysis, Pan 2. Chemical and Microbiological Properties. Agronomy Series No. 9 American Society of Agronomy, Madison, WI, USA.

Said, R. (1962). The Geology of Egypt, Elsevier, Amsterdam, 377 pp.

Schoeneberger, P. J., D. A. Wysocki, E. C. Benham and Soil Survey Staff (2012). Field book for describing and sampling soils. Version 3.0. Natural Resources Conservation Service, National Soil Survey Center, Lincoln, NE.

Soil Survey Division Staff (2017). 'Soil survey manual.' USDA Agriculture Handbook No. 18, Government Printing Office, Washington, D.C.

Soil Survey Staff (2014a). Keys to Soil Taxonomy, 12th ed. USDA-Natural Resources Conservation Service, Washington, DC.

Soil Survey Staff (2014b). Kellogg Soil Survey Laboratory Methods Manual. Soil Survey Investigations Report No. 42, version 5.0. R.
Burt and Soil Survey Staff (eds.). USDA Natural Resources Conservation Service.

Soltanpour, P. N. and A. P. Schwab (1977). A new soil test for simultaneous extraction of macro - and micro - nutrients in alkaline soils. Commun. Soil Sci. Plant Anal., 8: 195-207.

Suther, B. E. and D. S. Leigh (2020). Soil morphology of an alluvial chronosequence from the Little River, North Carolina Coastal Plain, USA, Geomorphology, 351: 106921

Tohidyan, S. and K. Rezaei-Moghaddam (2018). Impacts of the precision agricultural technologies in Iran: An analysis experts' perception \& their determinants. Information Processing in Agriculture, 5: 173-184.

Van Reeuwijk, L. P. (1993). Procedures for Soil Analysis, $4^{\text {th }}$ edition. International Soil Reference and Information Center, Wageningen, Netherland.

Voltz, M., D. Arrouays, A. Bispo, P. Lagacherie, B. Laroche, B. Lemercier, A. R. Forges, J. Sauter and N. Schnebelen (2020). Possible futures of soil-mapping in France. Geoderma Regional, 23: e00334. 


\title{
التخطيط المُتكامل لاستخذام الأراضي بوادي الأمل، محافظة أسوان، مصر
}

\author{
عادل عبد الحميد علوان خليل

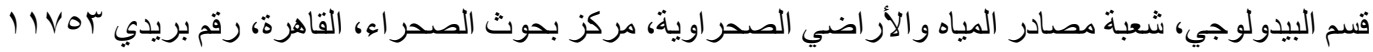

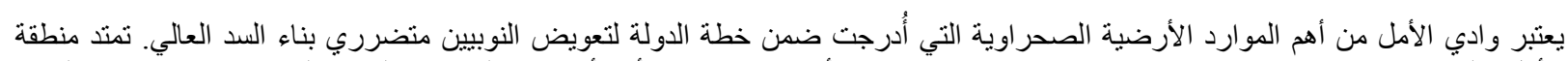

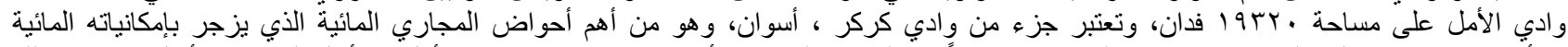

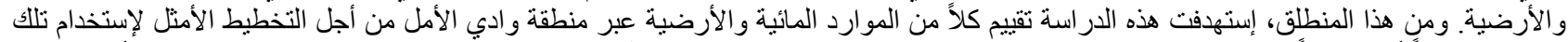

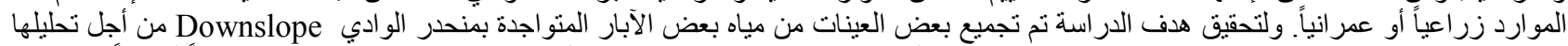

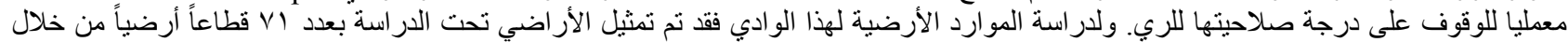

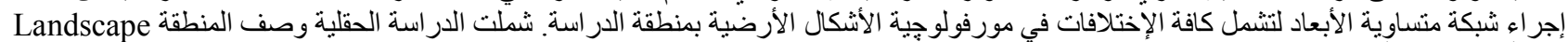

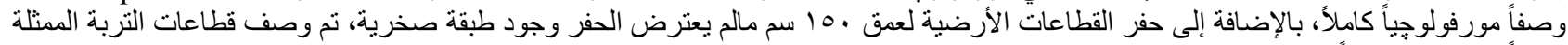

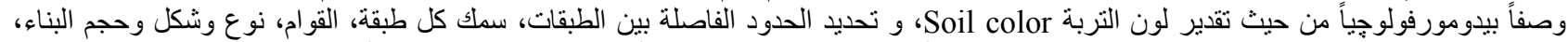

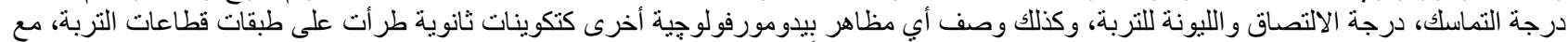

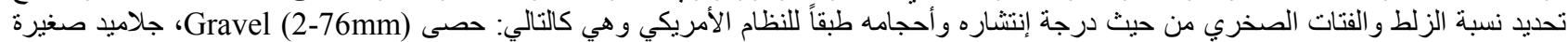

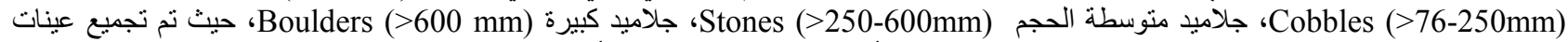

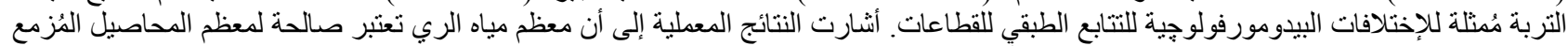

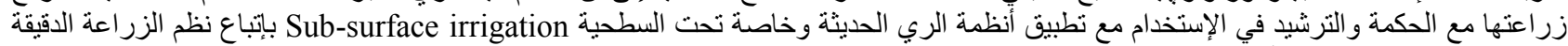

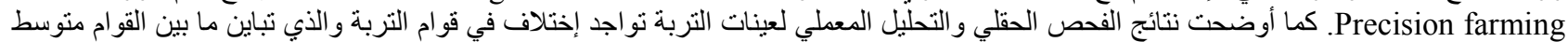

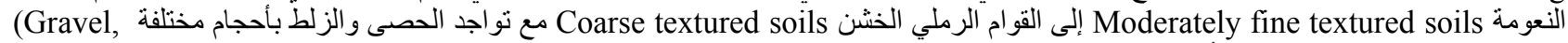

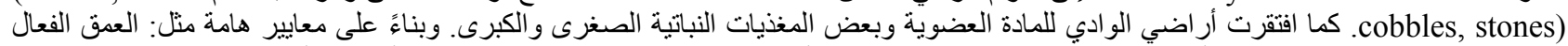

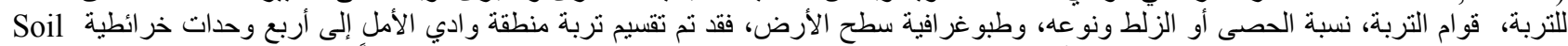

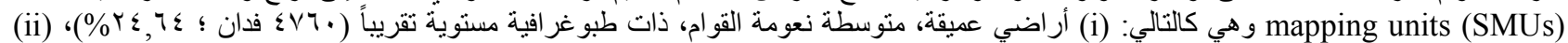

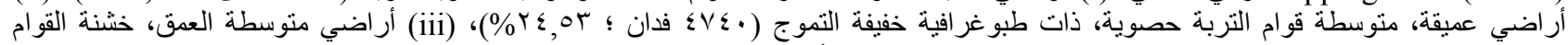

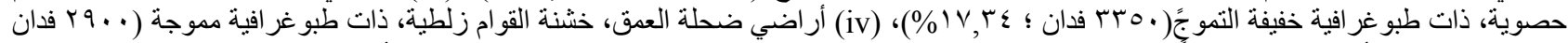

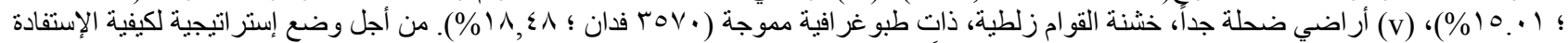

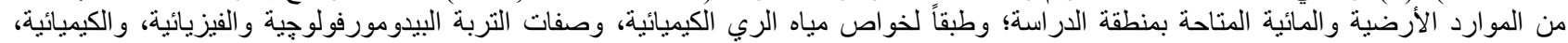

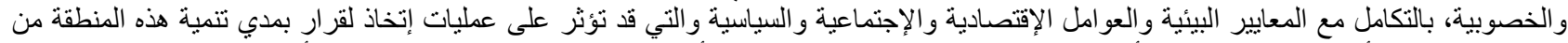

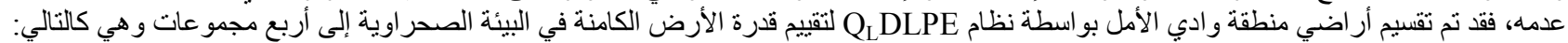

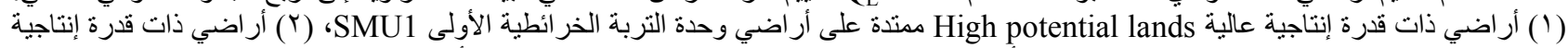

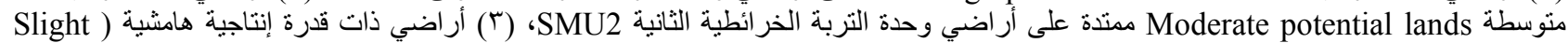

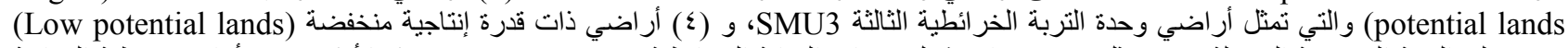

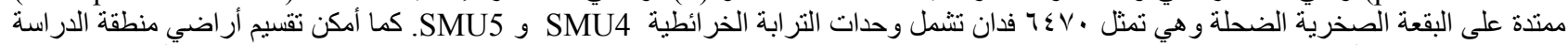

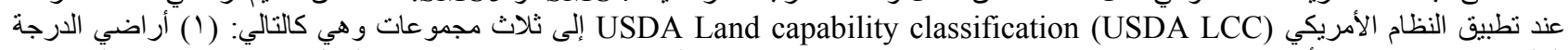

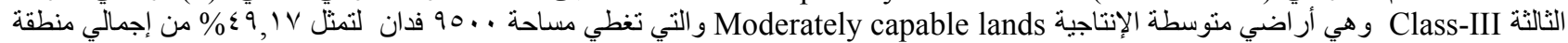

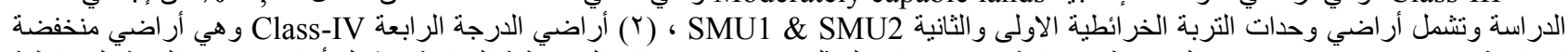

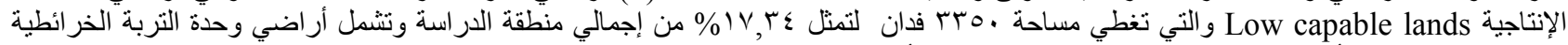

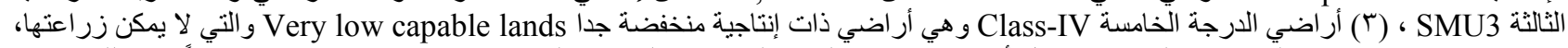

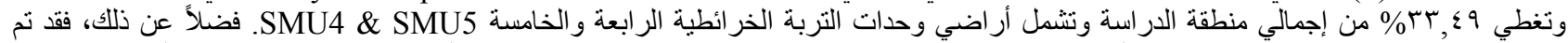

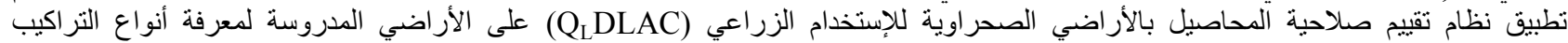

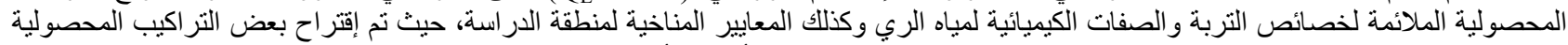
Land utilization types (LUTs)

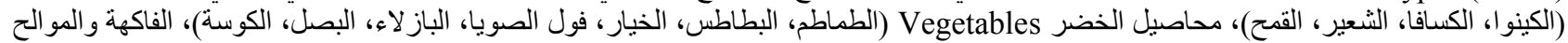

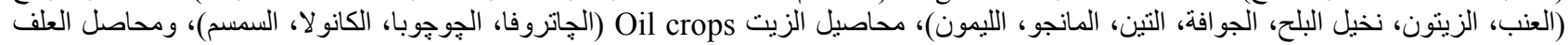

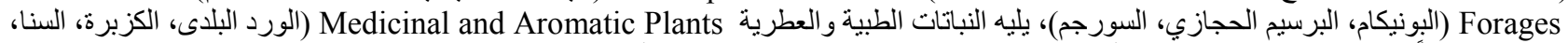

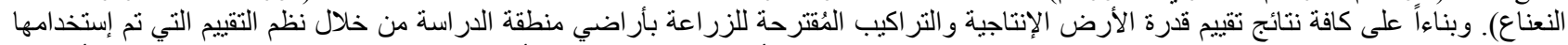

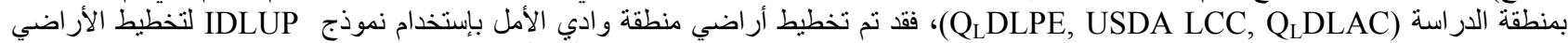

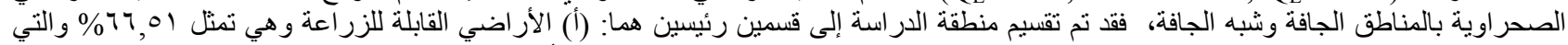

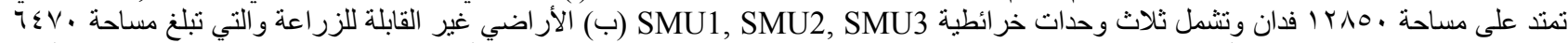

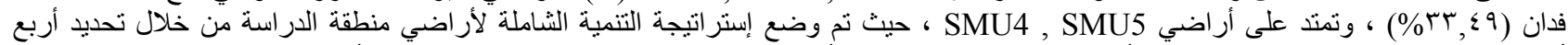

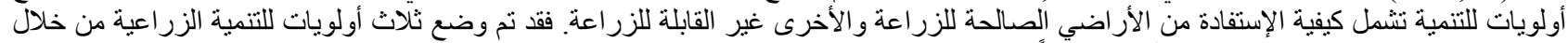

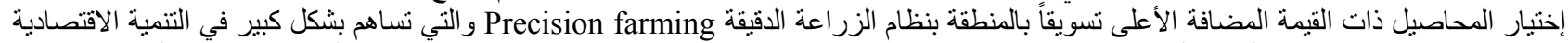

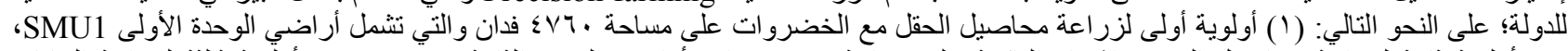

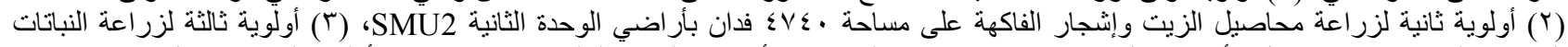

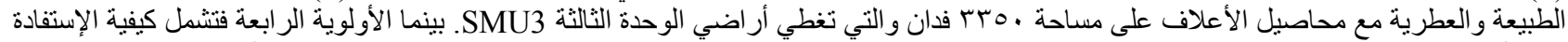

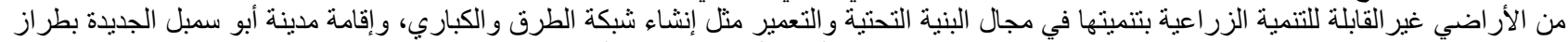

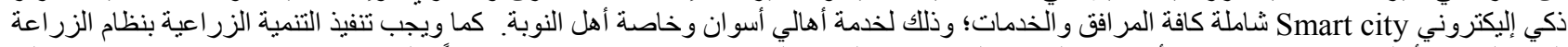

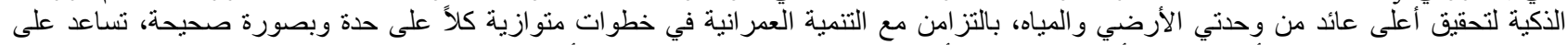

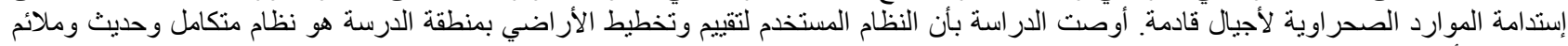
لظروف الأر اضي الصحر الوية ويمكن إستخدامه بشكل معنوي على مستوى العالم فيما يخص بتنمية مو ارد البيئة الصحر اوية في المناطق الجافة وشبه الجافة. 